\title{
The functions and clinical applications of tumor-derived exosomes
}

\author{
Yingkuan Shao ${ }^{1}$, Yanwei Shen ${ }^{1}$, Ting Chen ${ }^{1}$, Fei Xu ${ }^{1}$, Xuewen Chen ${ }^{2}$ and Shu Zheng ${ }^{1}$ \\ ${ }^{1}$ Cancer Institute (Key Laboratory of Cancer Prevention and Intervention, China National Ministry of Education, Key \\ Laboratory of Molecular Biology in Medical Sciences, Zhejiang Province, China), The Second Affiliated Hospital, Zhejiang \\ University School of Medicine, Hangzhou, Zhejiang, China \\ 2 Department of Biology, University of North Carolina, Chapel Hill, North Carolina, United States of America \\ Correspondence to: Shu Zheng, email: zhengshu@zju.edu.cn \\ Keywords: exosomes, solid tumor, metastasis, immunoregulation, clinical applications \\ Received: May16, $2016 \quad$ Accepted: July 13, $2016 \quad$ Published: August 10, 2016
}

\section{ABSTRACT}

Exosomes are extracellular vesicles with diameters ranging from 30 to $150 \mathrm{~nm}$. They can be secreted by all cell types and transfer information in the form of their contents, which include proteins, lipids and nucleic acids, to other cells throughout the body. They have roles in normal physiological processes as well as in disease development. Here, we review recent findings regarding tumor-derived exosomes, including methods for their extraction and preservation. We also describe the actions of exosomes in tumorigenesis. The exosomal antigen-presenting effect during antitumor immune responses and its suppressive function in immune tolerance are discussed. Finally, we describe the potential application of exosomes to cancer therapy and liquid biopsy.

\section{INTRODUCTION}

All prokaryotic and eukaryotic cells secrete extracellular vesicles (EVs) in order to exchange information [1]. Johnstone et al. first described EV formation during reticulocyte maturation [2]. Currently, EVs are classified into at least three main subgroups including microvesicles, apoptotic bodies, and exosomes. Exosomes in particular have been shown to play important roles in cardiovascular disease [3], neurological disease [4], and pain sensation [5]. Yáñez-Mó et al. provided a comprehensive review of our current understanding of the biological properties and physiological roles of EVs [1].

The role of exosomes in cancer development is of particular interest to oncologists because cancer cells secrete at least 10 -fold more exosomes than normal cells, and tumor-derived exosomes (TDEs) can facilitate cellcell communication through the transport of growth factors, chemokines, microRNAs, and other small molecules. Exosomes are protected by a lipid bilayer, which enables them to carry genetic information (e.g. miRNAs) to distant sites through the bloodstream. They may induce metastatic niche formation in target organs, which facilitates cancer cell colonization. Here, we first review the basic methodology for exosome extraction and preservation. Next, we discuss the exosomal antigen- presenting effect in the antitumor immune response and its suppressive function in immune tolerance. Finally, we describe potential applications for exosomes in cancer therapy and liquid biopsy.

\section{PREPARATION, IDENTIFICATION, AND PRESERVATION OF TUMOR-DERIVED EXOSOMES}

Initially, differential centrifugation was used to purify reticulocyte exosomes from tissue culture medium [2]. Taylor et al. first isolated circulating TDEs using modified magnetic-activated cell sorting protocol with anti-EpCAM in order to identify miRNA signatures in TDEs that could be used as diagnostic biomarkers in ovarian cancer [6]. The gold standard of exosome preparation is sucrose gradient enrichment after ultracentrifugation (UC). Thery et al. developed a protocol for the isolation and characterization of exosomes from both cell culture medium and biological fluids [7, 8]. However, Abramowicz et al. determined that UC combined with iodixanol density gradient centrifugation or gel filtration yielded higher quality exosomes. Importantly, this method was reliable and suitable for mass spectrometry [9]. Commercial exosome extraction kits also exist. Interestingly, Deun et al. performed a 
Table 1: Standard methods for exosome extraction

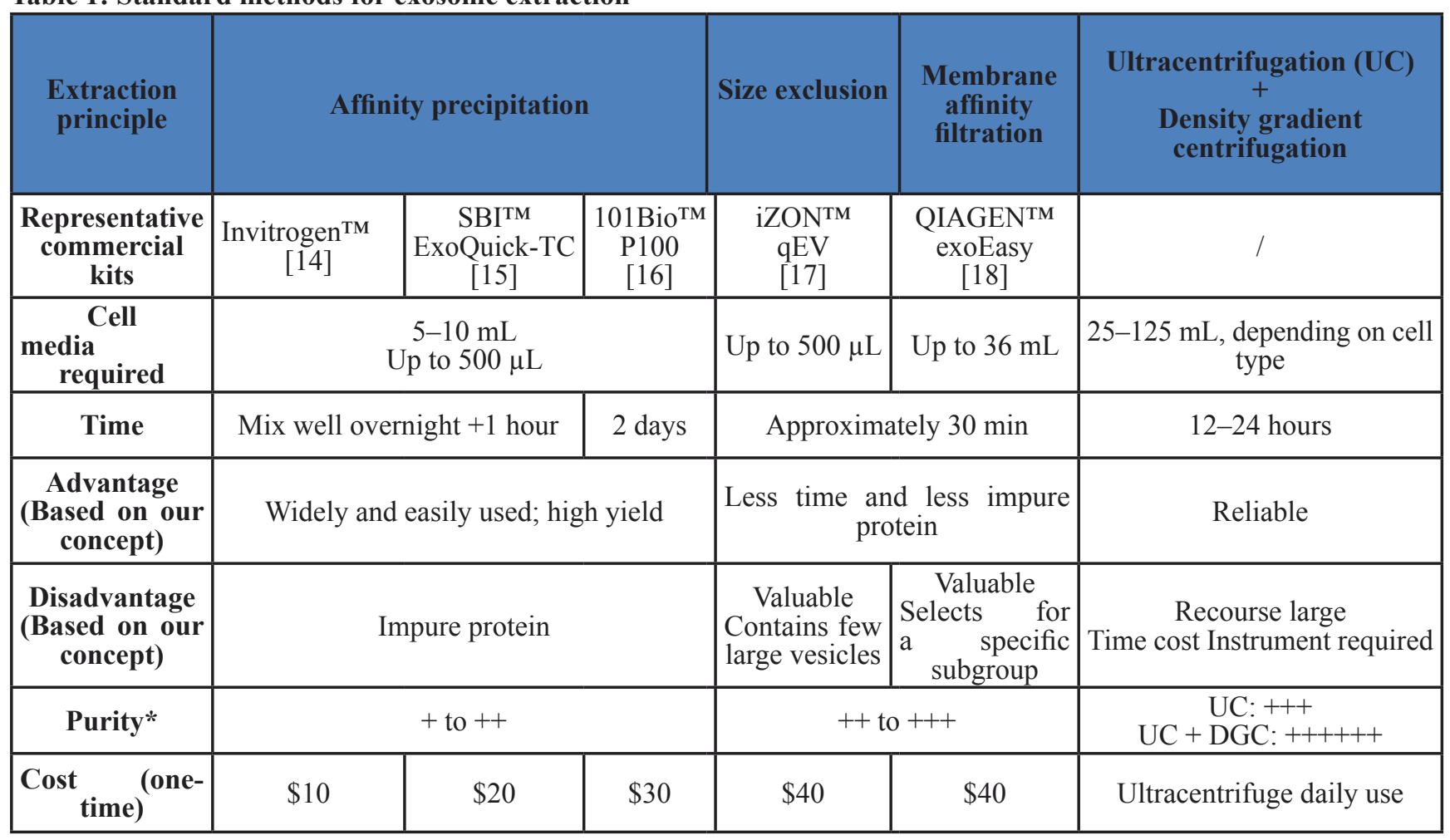

*Legend: +, very low; ++, low; +++, moderate; ++++, high; +++++, very high.

comparative analysis of UC, ultrafiltration, and several of these kits. The results indicated centrifuge-based methods for exosome concentration were optimal. Although commercial precipitation protocols could generate higher yields of concentrated exosomes, they provided the least pure preparations [10]. A summary of the advantages and disadvantages of the different extraction techniques is shown in Table 1.

Recently, a new method for exosome purification was developed based on the precipitation of EVs with polyethylene glycol. This was referred to as the "ExtraPEG" method [11]. This protocol is interesting because it is faster than ultrafiltration and costs less than commercial kits. We have obtained similar results in our lab, but still use the ultrafiltration and sucrose gradient method as the last step of our preparation to achieve a more pure population of exosomes. Weng et al. used a similar approach to isolate exosomes from cell culture supernatants for protein identification [12]. Overall, we believe that the most effective method is UC combined with density gradient centrifugation. Paolini et al. showed that UC alone had less of an ability to induce NF- $\mathrm{KB}$ nuclear translocation in endothelial cells, underscoring the need for density gradient centrifugation in addition to $\mathrm{UC}[13]$.

There are several alternative methods to extract exosomes if the original source is difficult to obtain. For example, exosomes can be isolated from various body fluids including serum, urine and cerebrospinal fluid [1924]. Yoshioka et al. developed a rapid and accurate liquid biopsy technique called Exoscreen to identify and quantify exosomes in blood samples [25]. In addition, Musante et al. developed a hydrostatic dialysis method for the isolation of exosomes from urine samples. The Musante method is highly cost-effective and maximizes the benefits of biobanking [26].

Following exosome isolation, the next step is to ensure the purity of the preparation. This step requires morphological analysis. Exosomes typically have diameters of 30-150 $\mathrm{nm}$. Transmission electron microscopy is therefore essential to obtain high-resolution images of exosomes. We recommend labeling exosomal membrane proteins such as CD9 prior to imaging [8]. Additional exosomal markers can be found here: http:// exocarta.org/exosome markers new. Negative controls are also recommended by the International Society for Extracellular Vesicles. These include Grp94 (HSP90B1) and calnexin (CANX), which are both markers of the endoplasmic reticulum, GM130 (a Golgi marker), cytochrome $\mathrm{C}$ (a mitochondrial marker), histones (nuclear markers), and Argonaute (AGO), which marks the RISC complex [27]. Fluorescence active cell sorting (FACS) and enzyme-linked immunosorbent assays (ELISA) are advantageous for high-throughput analysis. However, because other antigens can interfere with the assays, ELISA is not ideal for exosome detection. FACS analysis 
involves an advanced device designed for very small particles, but it has additional associated costs. Further, it can be difficult to detect the exact number of exosomes and estimate the concentration. Normally, direct cleavage of exosome surface proteins can be used to estimate the total protein concentration, but it is ideal to obtain a more precise number of exosomes. Therefore, Nanoparticle Tracking Analysis and qNano are typically used in these applications. There has also been progress in the development of microfluidics [28-31].

New insights regarding exosome preservation are emerging. Previous reports have indicated that exosomal size decreases by approximately $60 \%$ after storage at $37^{\circ} \mathrm{C}$ for 2 days. However, the original size is preserved when exosomes are stored at $-80^{\circ} \mathrm{C}$ for 2 days. It is also possible to preserve exosomes in either culture medium or phosphate-buffered saline at $-80^{\circ} \mathrm{C}$ for longer periods of time [32, 33]. However, exosomes isolated using the ExoQuick kit are only stable for up to $18 \mathrm{~h}$, even if they are stored at $-80^{\circ} \mathrm{C}$ [3]. Exosomes extracted by ultrafiltration or UC will begin to degrade and release their contents after $2 \mathrm{~h}$ of storage at $37^{\circ} \mathrm{C}$ [34]. Because the proteins and nucleic acids in exosomes are relatively unstable, storage at $-80^{\circ} \mathrm{C}$ is recommended.

\section{THE ROLES OF EXOSOMES IN THE METASTASIS OF SOLID TUMORS}

Cell-cell communication can occur through various signaling molecules including chemical and electrical. Valadi et al. proposed that communication could also be mediated by exosomal RNA (mRNAs and microRNAs) [35]. Interestingly, amplification of oncogenes was observed in EVs [36]. More recently, mitochondrial DNA (mtDNA) was detected in exosomes [37]. Finally, retrotransposon RNA transcripts and single-stranded DNA were detected in exosomes [38]. Detailed analyses of the nucleic acid content of TDEs has revealed the presence of both double-stranded DNA [39] and circular RNA [40]. It is important to note that mRNA mutants/variants and miRNAs have been detected in serum microvesicles [36]. Exosomal DNA was representative of the entire genome and the mutational status of the corresponding parental tumor cell $[38,39]$. Recently, exosome transfer from cancer cells to other cell types was observed in vivo. Using a Cre-LoxP-based approach, Zomer et al. observed uptake of EVs by tumor cells. Following uptake of EVs by more malignant cells, less malignant tumor cells displayed enhanced migratory behavior and metastatic capacity [41]. Malignant cells have the ability to transfer genetic information to other cells in the tumor microenvironment through exosomes. Examples of microRNA transport between cancer cells and tumor-associated cells through exosomes are shown in Table 2. Collectively, the data indicate that exosomal miRNAs contribute to cancer cell proliferation, metastasis, dormancy, and drug resistance.
The main functions of exosomes are described in Table 2. Here, we focus on the roles of exosomes in solid tumor metastasis. There are three general mechanisms by which cancer cells can communicate with other cells in the microenvironment. First, less invasive tumor cells can become more malignant by taking up microRNAs secreted by invasive tumor cells in exosomes. Melo et al. found that exosomes derived from either a malignant breast cancer cell line or serum from breast cancer patients instigated nontumorigenic epithelial cells to form tumors in mice via RISC-associated miRNAs. They observed an increase in cell proliferation and viability in non-malignant cells after treatment with exosomes derived from malignant cells [42]. Singh et al. found that metastatic MDA-MB-231 breast cancer cells had high expression of miR-10b and actively secreted exosomes containing this miRNA into the culture medium, which was not observed in cultures of non-metastatic or non-malignant cells. Exosomal miR$10 \mathrm{~b}$ suppressed the protein level of target genes such as HOXD10 and KLF4. Treatment with exosomes derived from MDA-MB-231 cells promoted invasion of nonmalignant cells [43]. RNA sequencing confirmed that exosomes contained more miRNAs than expected $[38,44$, 45 ] and indicated that they were not sorted into exosomes randomly $[46,47]$. Therefore, it is not surprising that malignant cells could alter the behavior of less malignant or non-malignant cells.

The second mechanism by which cancer cells can communicate with other cells in the tumor microenvironment is through exosomes. Zhou et al. determined that exosomes derived from metastatic breast cancer cells destroyed vascular endothelial barriers to promote metastasis through miR-105, which targets the tight junction protein ZO-1. Overexpression of miR-105 in non-metastatic cancer cells promoted metastasis and vascular permeability in distant organs following the destruction of tight junctions, which are natural barriers to metastasis [48]. The mechanisms by which exosomes function in pre-metastatic niche formation are of particular interest. Exosomes derived from tumor cells could be transported to specific organs [49]. It is possible that exosomes, which are representative of primary cancer cells, could perform similar functions in pre-metastatic niches to those performed by cancer cells at the primary tumor site (e.g. instigating endothelial cells and various types of macrophagocytes). Lyden et al. used the word "educating" to describe how exosomes alter the behavior of normal cells. They found that exosomes from highly metastatic melanomas enhanced the metastatic behavior of primary tumor cells through "educating" bone marrow progenitors [50]. They also determined that exosomes derived from pancreatic ductal adenocarcinomas were more frequently observed in the liver than in the lung. Exosomes containing macrophage migration inhibitory factor recruited macrophages from the bone marrow to the liver to help initiate pre-metastatic niche formation [51]. 
Table 2: Intercellular communication through exosome-derived microRNAs in different cancer models.

\begin{tabular}{|c|c|c|c|c|c|c|c|c|c|c|c|c|c|}
\hline Tumor & Donor & \multicolumn{2}{|c|}{ Contents } & \multicolumn{3}{|c|}{ Recipient } & \multicolumn{3}{|c|}{ Target(s) } & \multicolumn{2}{|c|}{ Function(s) } & Classification & Ref. \\
\hline \multirow{6}{*}{$\begin{array}{l}\text { Breast } \\
\text { cancer }\end{array}$} & MDA-MB-231 & \multicolumn{2}{|c|}{ miR-105 } & \multicolumn{3}{|c|}{ Endothelial cells } & \multicolumn{3}{|c|}{ Protein ZO-1 } & \multicolumn{2}{|r|}{$\begin{array}{l}\text { Destroys tight junctions and the integrity of natural barriers } \\
\text { to metastasis. }\end{array}$} & Metastasis & {$[48]$} \\
\hline & MDA-MB-231 & \multicolumn{2}{|c|}{$\operatorname{miR}-10 b$} & \multicolumn{3}{|c|}{ HMLE (MCF-7) } & \multicolumn{3}{|c|}{ HOXD10/KLF4 } & \multicolumn{2}{|c|}{ Induces invasion of non-malignant HMLE cells. } & Metastasis & {$[43]$} \\
\hline & $\begin{array}{l}\text { MDA-MB-231 } \\
4 \mathrm{~T} 1\end{array}$ & \multicolumn{2}{|c|}{$\operatorname{miR}-210$} & \multicolumn{3}{|c|}{ Endothelial cells } & \multicolumn{3}{|l|}{ / } & \multicolumn{2}{|r|}{$\begin{array}{l}\text { Suppresses expression of specific target genes resulting in } \\
\text { enhanced angiogenesis. }\end{array}$} & Metastasis & {$[66]$} \\
\hline & Endothelial cells & \multicolumn{2}{|c|}{ miR-503 } & \multicolumn{3}{|c|}{ Breast cancer cells } & \multicolumn{3}{|c|}{$\mathrm{CCND} 2 / \mathrm{CCND}$} & \multicolumn{2}{|c|}{ Alters proliferation and invasion. } & Metastasis & {$[67]$} \\
\hline & $\begin{array}{l}\text { EGCG-treated 4T1 } \\
\text { cells }\end{array}$ & \multicolumn{2}{|c|}{$\operatorname{miR}-16$} & \multicolumn{3}{|c|}{ Macrophages } & \multicolumn{3}{|l|}{ / } & \multicolumn{2}{|c|}{ Inhibits TAM infiltration and M2 polarization. } & Metastasis & {$[68]$} \\
\hline & $\begin{array}{l}\text { Mesenchymal } \\
\text { stem cells }\end{array}$ & miR-1 & & $4 \mathrm{~T}$ & & & & $\mathrm{EGF} \mathrm{mRN}$ & NA & $\begin{array}{l}\text { Down } \\
\text { growtl }\end{array}$ & $\begin{array}{l}\text {-regulates the expression of vascular endothelial } \\
\mathrm{h} \text { factor (VEGF) in tumor cells. }\end{array}$ & Metastasis & {$[69]$} \\
\hline Tumor & Donor & Conte & ents & & Reci & pient & & Target(s & & & Function(s) & Classification & Ref. \\
\hline & $\begin{array}{l}\text { Pre-adipocyte } \\
\text { (3T3L1) }\end{array}$ & miR-1 & & & MCF & & & SOX9 & & & Regulates differentiation, stemness, and migration. & Metastasis & {$[70]$} \\
\hline & $\begin{array}{ll}\text { Breast } & \\
\text { cancer } \\
\text { MCF10A }\end{array} \quad$ patients/ & miR-1 & 122 & & $\begin{array}{l}\text { Recip } \\
\text { meta } \\
\text { cells }\end{array}$ & $\begin{array}{l}\text { pient } \\
\text { astatic ni }\end{array}$ & & PKM2 a & and GI & LUT1 & $\begin{array}{l}\text { Suppresses glucose uptake by niche cells by down- } \\
\text { regulating pyruvate kinase }\end{array}$ & Proliferation & {$[71]$} \\
\hline & $\begin{array}{l}\text { Bone marrow } \\
\text { mesenchymal } \\
\text { stem cells }\end{array}$ & $\operatorname{miR}-2$ & $23 b$ & & $\begin{array}{l}\text { Breas } \\
\text { cells }\end{array}$ & ist can & & MARCK & $\mathrm{KS}$ & & $\begin{array}{l}\text { Decreases MARCKS expression and promotes } \\
\text { breast cancer cell dormancy in the metastatic niche. }\end{array}$ & Dormancy & {$[72]$} \\
\hline & $\begin{array}{l}\text { Bone marrow } \\
\text { stroma }\end{array}$ & $\begin{array}{l}\mathrm{miR}-1 \\
-222, a\end{array}$ & $\begin{array}{l}127,- \\
\text { and }-2\end{array}$ & 23 & MDA & A-MB-231 & & CXCL12 & & & $\begin{array}{l}\text { Reduce CXCL12 levels and decreases proliferation. } \\
\text { Elicit dormancy in bone marrow metastases in } \\
\text { breast cancer. }\end{array}$ & Dormancy & {$[73]$} \\
\hline cancer & \begin{tabular}{ll|} 
Hs578T & and \\
Hs578Ts(i)8 &
\end{tabular} & miR-1 & & & $\begin{array}{l}\text { Breas } \\
\text { cells }\end{array}$ & ist can & & STAT5B & & & $\begin{array}{l}\text { Reduces STAT5B and Hsp90 expression. Decreases } \\
\text { cell migration and invasion. }\end{array}$ & Drug resistance & {$[74]$} \\
\hline & $\begin{array}{l}\text { MCF-7 (Tamoxifen } \\
\text { resistant) }\end{array}$ & $\begin{array}{l}\operatorname{miR}-2 \\
-222\end{array}$ & 221/ & & $\begin{array}{l}\text { MCF } \\
\text { (Tam } \\
\text { sensi }\end{array}$ & $\begin{array}{l}\text {-7 } \\
\text { hoxifen- } \\
\text { itive) }\end{array}$ & & P27 and & $\mathrm{d} E R \alpha$ & & Enhances tamoxifen resistance in recipient cells. & Drug resistance & {$[75]$} \\
\hline & $\begin{array}{l}\text { IL-4-activated } \\
\text { macrophages }\end{array}$ & $\operatorname{miR}-2$ & & & MDA & A-MB-231 & & $\begin{array}{l}\text { Mef2c- } \\
\beta \text {-cateni }\end{array}$ & & & Promotes the invasion of breast cancer cells. & Metastasis & {$[76]$} \\
\hline & $\begin{array}{l}\text { Mesenchymal stem } \\
\text { cells }\end{array}$ & miR-1 & $124 /-1$ & & $\begin{array}{l}\text { Glior } \\
\text { glion }\end{array}$ & $\begin{array}{l}\text { ma cells } \\
\text { na stem ce }\end{array}$ & & $\mathrm{SCP}-1 / \mathrm{S}$ & Sox2 & & $\begin{array}{l}\text { Decrease the migration of glioma cells and the self- } \\
\text { renewal of glioma stem cells. }\end{array}$ & Proliferation & {$[77]$} \\
\hline & $\begin{array}{l}\text { Bone marrow- } \\
\text { derived MSCs }\end{array}$ & $\begin{array}{l}\operatorname{miR}-2 \\
-3 a\end{array}$ & & & $\begin{array}{l}\text { Breas } \\
\text { cells }\end{array}$ & ist can & ceer & $\begin{array}{l}\text { TPM1/P } \\
\text { Bcl-2 }\end{array}$ & $\mathrm{PDCD}$ & & Elicit pro-tumorigenic and anti-apoptotic effects. & Proliferation & {$[78]$} \\
\hline Lung cancer & Immune cells & $\begin{array}{l}\mathrm{miR}-1 \\
-146 \mathrm{a}\end{array}$ & $155 /$ & & $\operatorname{Imm}$ & une cells & & $\begin{array}{l}\text { HO1/ I } \\
\text { TRAF6 }\end{array}$ & ${ }_{6}^{\text {IRAK }}$ & 1 and & $\begin{array}{l}\text { MiR-155 enhances while miR-146a reduces } \\
\text { inflammatory gene expression. Promotes endotoxin- } \\
\text { induced inflammation. }\end{array}$ & Inflammation & {$[79]$} \\
\hline & Mast cell & 1 & & & A549 & & & KIT-SCI & $\mathrm{CF} / \mathrm{PI} 3$ & & Enhances proliferation in recipient tumor cells. & Proliferation & {$[80]$} \\
\hline Tumor & Oonor & Cont & ents & $\operatorname{Re}$ & cipien & & Tar & $\operatorname{rget}(s)$ & & Inction( & & Classification & Ref. \\
\hline & 549 & $\operatorname{miR}-1$ & & Enc & dotheli & lial cells & $\begin{array}{ll}\mathrm{IC} A \\
\mathrm{PT}\end{array}$ & $\begin{array}{l}\text { AM-1/ } \\
\text { PRJ }\end{array}$ & & $\begin{array}{l}\text { gulates } \\
\text { luced os }\end{array}$ & $\begin{array}{l}\text { non-cell-autonomous invasiveness, and tumor- } \\
\text { steoclastogenesis. }\end{array}$ & Bone metastasis & {$[81]$} \\
\hline & $\begin{array}{l}\text { 3ronchial } \text { epithelial } \\
\text { HBE) cells }\end{array}$ & miR-2 & & No & rmal H & HBE cells & $\mathrm{ST}$ & AT3 & & $\begin{array}{l}\text { creases } \\
\text { angioge }\end{array}$ & $\begin{array}{l}\text { VEGF levels in recipient cells, which is involved } \\
\text { enesis and malignant transformation of HBE cells. }\end{array}$ & Angiogenesis & {$[82]$} \\
\hline & ung adenocarcinoma & miR-2 & & Str & omal c & cells & Epl & hrin A3 & & omotes & angiogenesis. & Angiogenesis & {$[83]$} \\
\hline $\begin{array}{l}\text { Lung } \\
\text { cancer }\end{array}$ & $\begin{array}{l}\text { ung cancer A-549 and } \\
\text { K-MES cells }\end{array}$ & $\begin{array}{l}\operatorname{miR}-2 \\
-29 a\end{array}$ & & $\operatorname{Im}$ & mune $c$ & cells & $\begin{array}{l}\text { Tol } \\
\text { rec } \\
\text { (TL } \\
\text { (TL }\end{array}$ & $\begin{array}{l}\text { l-like } \\
\text { eptors } \\
\text { R7) and } \\
\text { R8) }\end{array}$ & $\begin{array}{r}7 \\
8\end{array}$ & $\begin{array}{l}\text { omote } \mathrm{P} \\
\text { lammat }\end{array}$ & $\begin{array}{l}\mathrm{NF}-\mathrm{kB} \text { activation and the secretion of pro-metastatic } \\
\text { tory cytokines. }\end{array}$ & Pre-metastasis & {$[84]$} \\
\hline & 549 & miR-1 & 192 & Enc & dotheli & lial cells & $\begin{array}{ll}\text { IC } A \\
\text { PTI }\end{array}$ & $\begin{array}{l}\text { AM-1/ } \\
\text { PRJ }\end{array}$ & & $\begin{array}{l}\text { gulates } \\
\text { luced os }\end{array}$ & $\begin{array}{l}\text { non-cell-autonomous invasiveness, and tumor- } \\
\text { steoclastogenesis. }\end{array}$ & Bone metastasis & [81] \\
\hline & $\begin{array}{l}\text { 3ronchial epithelial } \\
\text { HBE) cells }\end{array}$ & miR-2 & & No & rmal H & HBE cells & $\mathrm{ST}$ & AT3 & & $\begin{array}{l}\text { creases } \\
\text { angioge }\end{array}$ & $\begin{array}{l}\text { VEGF levels in recipient cells, which is involved } \\
\text { enesis and malignant transformation of HBE cells. }\end{array}$ & Angiogenesis & {$[82]$} \\
\hline & denocarcinoma & miR-2 & 210 & Str & omal c & cells & Epl & hrin A3 & & omotes & angiogenesis. & Angiogenesis & {$[83]$} \\
\hline & $\begin{array}{l}\text { ung cancer A-549 and } \\
\text { K-MES cells }\end{array}$ & $\begin{array}{l}\operatorname{miR}-2 \\
-29 a\end{array}$ & & $\operatorname{Im} \mathrm{I}$ & mune $c$ & cells & $\begin{array}{l}\text { Tol } \\
\text { rec }\end{array}$ & $\begin{array}{l}\text { 1-like } \\
\text { eptors } 7 / 8\end{array}$ & $\begin{array}{l}\text { Pro } \\
\text { inf }\end{array}$ & $\begin{array}{l}\text { omote } \mathrm{P} \\
\text { lammat }\end{array}$ & $\begin{array}{l}\mathrm{NF}-\mathrm{kB} \text { activation and the secretion of pro-metastatic } \\
\text { tory cytokines. }\end{array}$ & Metastasis & {$[84]$} \\
\hline Tumor & Donor & & Con & tents & & Recipien & & & Targe & et(s) & Function(s) & Classification & Ref. \\
\hline Prostate & $\begin{array}{l}\text { Docetaxel-resistant } \\
\text { prostate cancer cells }\end{array}$ & & $\operatorname{miR}$ & $-34 a$ & & Docetaxe & el-res & sistant & $\begin{array}{l}\text { B-cel } \\
\text { Lymp }\end{array}$ & homa 2 & $\begin{array}{l}\text { Influences cell response to docetaxel in prostate } \\
\text { cancer cells through regulation of anti-apoptotic } \\
\text { BCL-2. }\end{array}$ & Drug resistance & {$[85]$} \\
\hline & DIAPH3-silenced ce & & $\operatorname{miR}$ & -125 & & macroph & lages & & AKT & & $\begin{array}{l}\text { Suppresses AKT1 expression and proliferation } \\
\text { of cancer. }\end{array}$ & Proliferation & {$[86]$} \\
\hline $\begin{array}{l}\text { Bladder } \\
\text { cancer }\end{array}$ & $\begin{array}{l}\text { Exosome-derived } \\
29 \mathrm{c}\end{array}$ & miR- & $\operatorname{miR}$ & $-29 c$ & & BIU-87 C & cells & & $\begin{array}{l}\text { BCL- } \\
\text { MCL }\end{array}$ & $\begin{array}{l}-2 \\
-1\end{array}$ & \begin{tabular}{l|l} 
and & $\begin{array}{l}\text { Exosome-derived microRNA29c induces } \\
\text { apoptosis in bladder cancer cells by down- } \\
\text { regulating BCL-2 and MCL-1. }\end{array}$
\end{tabular} & Apoptosis & [87] \\
\hline Molom & A375 and SK-MEL- & & $\begin{array}{l}\operatorname{miR} \\
\text { and }\end{array}$ & $\begin{array}{l}-31, \\
-34 b\end{array}$ & -185 & Normal 1 & mela & nocytes & $\begin{array}{l}\text { HAPI } \\
\text { GRP7 }\end{array}$ & $\begin{array}{ll}\mathrm{LN} 1 \\
78\end{array}$ & 1 & Metastasis & {$[88]$} \\
\hline & $\begin{array}{l}\text { Metastatic melanon } \\
\text { lines }\end{array}$ & na cell & $\mathrm{miR}$ & -222 & & $\begin{array}{l}\text { Primary } \\
\text { cell lines }\end{array}$ & & lanoma & $\mathrm{p} 27 \mathrm{~K}$ & ip1 & Activates the PI3K/AKT pathway. & Metastasis & [89] \\
\hline
\end{tabular}




\begin{tabular}{|c|c|c|c|c|c|c|c|c|c|c|c|c|c|c|}
\hline $\begin{array}{l}\text { Colorectal } \\
\text { cancer }\end{array}$ & \multicolumn{3}{|c|}{$\begin{array}{l}\text { HCT-15, SW480 and } \\
\text { WiDr }\end{array}$} & \multicolumn{2}{|c|}{$\begin{array}{l}\operatorname{miR}-21,-192 \\
\text { and }-221\end{array}$} & \multicolumn{3}{|c|}{ HepG2 and A549 } & \multicolumn{2}{|l|}{1} & \multicolumn{2}{|l|}{$\begin{array}{l}\text { Regulate the expression of target genes in } \\
\text { HepG2 and A549 cells. May promote various } \\
\text { functions. }\end{array}$} & / & {$[90]$} \\
\hline \multirow{2}{*}{$\begin{array}{l}\text { Gastric } \\
\text { cancer }\end{array}$} & \multicolumn{3}{|c|}{ Macrophage } & \multicolumn{2}{|l|}{ miR-21 } & \multicolumn{3}{|c|}{ BGC-823 } & \multicolumn{2}{|l|}{ PDCD4 } & \multicolumn{2}{|l|}{$\begin{array}{l}\text { MiR-21 inhibitor-loaded exosomes promote } \\
\text { migration and reduce apoptosis. }\end{array}$} & Metastasis & [91] \\
\hline & \multicolumn{3}{|c|}{ Mesenchymal stem cells } & \multicolumn{2}{|c|}{ miR-221 } & \multicolumn{3}{|c|}{ HGC-27 } & \multicolumn{2}{|l|}{1} & \multicolumn{2}{|l|}{ Promotes HGC-27 growth and migration. } & Metastasis & {$[92]$} \\
\hline \multicolumn{2}{|l|}{ Tumor } & \multicolumn{2}{|l|}{ Donor } & \multicolumn{2}{|c|}{ Contents } & \multicolumn{3}{|c|}{ Recipient } & \multicolumn{2}{|l|}{ Target(s) } & \multicolumn{2}{|l|}{ Function(s) } & Classification & Ref. \\
\hline \multirow{2}{*}{\multicolumn{2}{|c|}{ Gastric cancer }} & \multicolumn{2}{|l|}{ AZ-P7a } & \multicolumn{2}{|l|}{ Let-7 } & $\mathrm{AZ}$ & -521 & & $\begin{array}{l}\text { RAS } \\
\text { HMGA2 }\end{array}$ & and & Induces tumorigenesis and metastasis. & & Metastasis & [93] \\
\hline & & OCUM-2MD & & $\begin{array}{l}\operatorname{miR}-21 \\
-1225-5 p\end{array}$ & and & $\mathrm{OC}$ & UM-2M & & 1 & & $\begin{array}{l}\text { MiR-21 and miR-1225-5p may prepare a } \\
\text { metastatic niche in the peritoneum for } \\
\text { dissemination and colonization of metast } \\
\text { cancer cells. }\end{array}$ & $\begin{array}{r}\text { pre- } \\
\text { the } \\
\text { tatic }\end{array}$ & Metastasis & [94] \\
\hline & & Macrophages & & $\begin{array}{l}\operatorname{miR}-142 \\
-223\end{array}$ & and & $\begin{array}{l}\mathrm{Hep} \\
\mathrm{carc} \\
\mathrm{(Hu}\end{array}$ & $\begin{array}{l}\text { patocellular } \\
\text { cinoma c } \\
\text { lH7 and Hep }\end{array}$ & & $\begin{array}{l}\text { Stathmin-1 } \\
\text { IGF1R }\end{array}$ & & Inhibits proliferation of cancer cells. & & Inhibitor & {$[95]$} \\
\hline Liver can & & Huh7 cells & & $\operatorname{miR}-122$ & & Hep & pG2 cells & & IGF1R mR & RA & $\begin{array}{l}\text { Reduced growth and proliferation of recip } \\
\text { HepG } 2 \text { cells. }\end{array}$ & ient & Inhibitor & [96] \\
\hline & & $\begin{array}{l}\text { Hep3B, Hep } \\
\text { and PLC/PRF }\end{array}$ & $\mathrm{F} / 5$ & $\operatorname{miR}-584$ & & $\begin{array}{l}\text { Hep } \\
\text { PLC }\end{array}$ & $\begin{array}{l}\text { p3B, HepG2 } \\
\text { C/PRF/5 }\end{array}$ & and & $\begin{array}{l}\text { TGF- } \beta \\
\text { activated } \\
\text { kinase-1 } \\
\text { (TAK1) }\end{array}$ & & $\begin{array}{l}\text { HCC cell-derived exosomes modulate TA } \\
\text { expression and associated signaling. They } \\
\text { enhance the growth of transformed recipient ce }\end{array}$ & $\begin{array}{l}\text { AK1 } \\
\text { also } \\
\text { ells. }\end{array}$ & Proliferation & [97] \\
\hline Cholangic & arcinoma & $\begin{array}{l}\text { KMBC } \\
\text { HuCCT1 }\end{array}$ & and & / & & $\begin{array}{l}\text { Me: } \\
\text { cell }\end{array}$ & $\begin{array}{l}\text { senchymal st } \\
\text { ls }\end{array}$ & tem & / & & $\begin{array}{l}\text { Enhance MSC migratory capability } \\
\text { expression of alpha-smooth muscle actin mRI } \\
\text { Promote the release of CXCL-1, CCL2, and Il }\end{array}$ & $\begin{array}{l}\text { and } \\
\text { NA. } \\
\text { L-6. }\end{array}$ & Metastasis & [98] \\
\hline Tumor & & onor & Cont & tents & Reci| & pient & & Targ & $\operatorname{get}(\mathrm{s})$ & Fun & etion(s) & Clas & ssification & Ref. \\
\hline & & $\begin{array}{l}562 \text { under } \\
\text { poxic } \\
\text { mditions }\end{array}$ & $\operatorname{miR}-$ & -210 & $\begin{array}{l}\text { Umb } \\
\text { endot }\end{array}$ & $\begin{array}{l}\text { ilical } \\
\text { thelia }\end{array}$ & al cells & EFN & NA3 & $\begin{array}{l}\text { Exo } \\
\text { und } \\
\text { activ }\end{array}$ & $\begin{array}{l}\text { somal miRNAs derived from cancer cells } \\
\text { ler hypoxic conditions may affect angiogenic } \\
\text { vity in endothelial cells. }\end{array}$ & Met: & tastasis & [99] \\
\hline & & AMA84 & $\operatorname{miR}-$ & -126 & Endo & theli & al cells & $\begin{array}{l}\text { CXC } \\
\text { VCA }\end{array}$ & $\begin{array}{l}\text { CL12 and } \\
\text { AM1 }\end{array}$ & $\begin{array}{l}\mathrm{HU} \\
\text { the } \\
\text { adhe }\end{array}$ & $\begin{array}{l}\text { VECs with a miR-126 inhibitor reversed } \\
\text { decrease in CXCL12, restores motility and } \\
\text { esion in LAMA } 84 \text { cells. }\end{array}$ & Mete & tastasis & {$[100]$} \\
\hline $\begin{array}{l}\text { Hematolo } \\
\text { malignan }\end{array}$ & & $\begin{array}{l}\text { hronic } \\
\text { mphocytic } \\
\text { ukemia } \\
\text { MEC1) }\end{array}$ & $\mathrm{miR}-$ & $-202-3 p$ & Hum & Ian st & romal cells & $\mathrm{c}-\mathrm{Fo}$ & os and ATM & Enh & lances proliferation of recipient cells. & Proli & liferation & {$[101]$} \\
\hline & & 562 cells & $\operatorname{miR}-$ & $-92 \mathrm{a}$ & $\begin{array}{l}\text { Umb } \\
\text { endot }\end{array}$ & $\begin{array}{l}\text { ilica } \\
\text { thelis }\end{array}$ & al cells & Integ & grin $\alpha 5$ & $\begin{array}{l}\text { Enh } \\
\text { form }\end{array}$ & $\begin{array}{l}\text { nances endothelial cell migration and tube } \\
\text { nation. }\end{array}$ & Met: & tastasis & {$[102]$} \\
\hline & & LL cells & $\operatorname{miR}-$ & & $\begin{array}{l}\text { MSC } \\
\text { endot }\end{array}$ & is & al cells ${ }^{\text {and }}$ & / & & $\begin{array}{l}\text { Indu } \\
\text { asso }\end{array}$ & $\begin{array}{l}\text { uce differentiation of stromal cells into cancer- } \\
\text { ociated fibroblasts. }\end{array}$ & Meta & tastasis & {$[103]$} \\
\hline & & $\begin{array}{l}\text { Iultiple } \\
\text { yeloma cells }\end{array}$ & $\operatorname{miR}-$ & $-135 b$ & endot & thelis & al cells & FIH- & & $\begin{array}{l}\text { Exo } \\
\text { enh } \\
\text { hyp } \\
\text { path }\end{array}$ & $\begin{array}{l}\text { somal miR-135b from HR-MM cells } \\
\text { ances endothelial tube formation under } \\
\text { oxic conditions via the HIF-FIH signaling } \\
\text { away. }\end{array}$ & Mete & tastasis & {$[104]$} \\
\hline Neurobla & $\mathrm{N}$ & BL cells & $\mathrm{miR}-$ & & Hum & $\operatorname{an} \mathrm{m}$ & onocytes & TLR & R8-NF-кB & & & Druo & 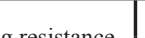 & {$[105]$} \\
\hline Neturodias & Oilla & lonocytes & miR- & -155 & NBL & cells & & TER & RF1 & & & Drug & g resistance & [105] \\
\hline Tumor & Donor & & & Conten & & & Recipient & Tar & rget(s) & unctic & on(s) & Clas & ssification & Ref. \\
\hline & SKOV-3 & & & let-7 fa & nily & & OVCAR-3 & / & & $\begin{array}{l}\text { Exoson } \\
\text { ines an }\end{array}$ & $\begin{array}{l}\text { ne release varies between ovarian cancer cell } \\
\text { hd is correlated with invasive potential. }\end{array}$ & Meta & tastasis & {$[106]$} \\
\hline & CP70 & & & $\mathrm{miR}-21$ & & & A2780 & NA & AV3 & ncreas & es platinum-resistance in A2780 cells. & Drug & g resistance & {$[107]$} \\
\hline $\begin{array}{l}\text { Ovarian } \\
\text { cancer }\end{array}$ & High-grad & e ovarian cance & & $\begin{array}{l}\text { ATF2, } \\
\text { and RO }\end{array}$ & $\begin{array}{r}\text { MTA } \\
\text { CK1/2 }\end{array}$ & & $\begin{array}{l}\text { Endothelial } \\
\text { cells }\end{array}$ & / & & $\begin{array}{l}\text { Exoson } \\
\text { lter a } \\
\text { varian }\end{array}$ & $\begin{array}{l}\text { mes derived from high-grade ovarian cancer } \\
\text { angiogenesis compared to non-high-grade } \\
\text { cancer cells. }\end{array}$ & Mete & tastasis & {$[108]$} \\
\hline & $\begin{array}{l}\text { The seru } \\
\text { NPC or T }\end{array}$ & $\begin{array}{l}\mathrm{n} \text { of patients } \\
\text { N03 cells }\end{array}$ & with & $\begin{array}{l}\operatorname{miR}-24 \\
-891 \mathrm{a}, \\
5 \mathrm{p}\end{array}$ & $\begin{array}{l}3 p, \\
\text { nd }-10\end{array}$ & & T-cell & & ARK1 & Alter T- & -cell proliferation and differentiation. & Met: & tastasis & {$[109]$} \\
\hline
\end{tabular}

An analogous mechanism was discovered in pancreatic cancer. Exosomes from pancreatic ductal adenocarcinomas fused with resident cells at the metastatic location, which included liver Kupffer cells and lung epithelial cells. In addition, exosome integrin uptake by resident cells activated Src and altered the expression of pro-migratory and pro-inflammatory S100 genes, which are associated with metastasis [52]. Grange et al. reported that in human renal cell carcinoma, microvesicles released by CD105 positive tumor-initiating cells promoted angiogenesis and enhanced lung metastasis [53]. All of the work we have described is based on in vitro studies of purified TDEs. Whether TDEs perform these functions in vivo is still not clear [54]. Our data indicate that colorectal cancer-derived exosomes could be used to predict organspecific metastasis (unpublished data).

A third mode of communication involves exosomes derived from normal cells, which can alter the behavior of tumor cells. Zhang et al. revealed that both human and mouse tumor cells lost PTEN expression after metastasis to the brain, but not to other organs. They determined that PTEN expression was regulated by microRNAs from brain astrocytes [55]. These results indicate that organspecific metastasis is not only determined by TDEs, but 
also by specific organ-associated cells. In Table 2 we have concluded other models of this kind of transferring. Interestingly, TDEs can fuse with non-parenchymal cells in various organs, leading to inflammation, anoxia, and vascularization in the metastatic microenvironment. Collectively, the data indicate that exosomes play important roles in pre-metastatic niche formation.

Quantitative proteomic analysis of EVs has resulted in the identification of proteins in exosomal membranes and lumens, which may contribute to metastasis [5659]. Public databases including Vesiclepedia (www. microvesicles.org) [60], EVpedia (www.evpedia.info) [61, 62], and ExoCarta (www.exocarta.org) [63] can be used to identify exosomal proteins. For example, Timothy et al. searched all of the proteins in the Vesiclepedia database and used a gene ontology approach to identify regulatory factors involved in cancer initiation and progression [64]. Additionally, Ostenfeld et al. determined that exosomes derived from a metastatic human bladder carcinoma cell line had high expression of vimentin and hepatomaderived growth factor in the membrane, and casein kinase II and annexin A2 in the lumen using quantitative isobaric tags for relative and absolute quantitative proteomics [57]. Finally, Lee et al. performed a proteomic analysis to identify differences in protein expression between MCF-7 and MDA-MB-231 cells, and described a new function for EDIL3 on EVs, which enhanced cell invasion and lung metastasis in vivo [65].

\section{THE ROLES OF TUMOR-DERIVED EXOSOMES IN THE ANTI-TUMOR IMMUNE RESPONSE}

\section{Exosomal antigen presentation in the antitumor immune response}

TDEs contain tumor-associated antigens (TAAs) and major histocompatibility complex (MHC) class I molecules $[110,111]$. Exosomes deliver TAAs to dendritic cells (DCs), which results in the induction of antigenspecific CD8 T-cells and tumor rejection in various prophylaxis and therapeutic murine tumor xenograft models. Importantly, coupling of TAAs to exosomes elicited a more efficient antitumor immune response and had a stronger therapeutic effect compared to subcutaneous delivery of TAAs in a mouse fibrosarcoma model [112]. DCs loaded with syngeneic or allogeneic TDEs stimulated regression of pre-established tumors in mice $[110,111]$. Another approach to exosome-based cancer immunotherapy involves the applications of DCs pulsed with tumor peptides [113-116]. Both mouse and human TAA-loaded DCs can secrete exosomes that express functional MHC class I, II, and T-cell co-stimulatory molecules. These exosomes have been reported to stimulate tumor-specific CD8 T-cells in vivo and inhibit the growth of transplanted tumors in mice. Clinical grade exosomes were first isolated from DCs and characterized. They were then evaluated in clinical trials for various cancers [116-118]. In a phase I clinical trial, exosomes derived from autologous DCs loaded with MAGE 3 peptides were investigated in stage III/IV melanoma patients [117]. This was the first trial to demonstrate the feasibility of large-scale exosome production and safety of exosome administration. Several other phase I or phase II clinical trials involving exosome-based regimens have been initiated in patients with non-small cell lung cancer, malignant glioma, breast cancer, and gastric cancer [118].

\section{The immunosuppressive effects of tumor-derived exosomes}

TDEs are a major source of tumor antigens. However, recent studies have shown that TDEs can also suppress antigen-specific or non-specific anti-tumor responses. For example, TDEs are rich in FasL, TRAIL, and galectin-9, which stimulate T-cell apoptosis [119-121]. Moreover, TDEs suppress CD3- $\zeta$ chain expression in T-cells, which prevents activation [122]. They also inhibit NKG2D-dependent cytotoxicity in natural killer cells and CD8 T-cells [123].

In addition to the effects of TDEs on T-cells and natural killer cells, TDEs also modulate antigen-presenting cells, which controls differentiation. For example, they can induce monocyte differentiation into myeloid-derived suppressor cells (MDSCs), which inhibit the antitumor immune response [123]. The prostaglandin E2, TGF- $\beta$, Hsp70, and miRNAs contained in tumor-derived vesicles play important roles in monocyte differentiation [124126]. Moreover, in tumor-bearing mice, blood-borne exosomes positive for CD11b could suppress tumor Agspecific responses through a MHC Class-II dependent and MHC Class-I independent mechanism [127]. These observations suggest that TDEs initially stimulate CD11-positive antigen presenting cells in the tumor microenvironment, which then secrete immunosuppressive MHC Class-II, CD11b-positive vesicles into the circulation. Exosomes released by human melanoma and colorectal carcinoma cells impair differentiation of blood CD14+ monocytes into immune-stimulating DCs and replace them with highly immunosuppressive MDSCs that inhibit T-cell functions through secretion of TGF-b [123, 128]. Thus, the MDSC generation, expansion, migration, and activation are controlled by various mediators of chronic inflammation [129-132].

Intriguingly, all of these factors have been observed in the tumor microenvironment in a soluble form. However, recent studies have indicated that they can be transported to distant locations by TDEs, which alters the differentiation and function of myeloid cells in the 
favor of immunosuppressive MDSCs at metastatic sites $[129,130,133]$. MDSCs then induce or support the functions of regulatory T-cells (Tregs), which have key roles in the tumor-suppressive microenvironment. In addition, TDEs can enhance Treg function and inhibit apoptosis. For example, the expression of membranebound TGF-b and other cytokines, growth factors, and matrix metalloproteinases from MDSCs are capable of directing CD4+ T-cells towards the Th2 and Treg lineages [134-137]. Finally, exosomes have been shown to convert conventional CD4+FoxP3- T-cells into highly suppressive and apoptosis-resistant Tregs via TGF-b and IL-10, and to promote Treg expansion $[138,139]$.

\section{TUMOR-DERIVED EXOSOMES IN CLINICAL PRACTICE}

\section{The concentrations of exosomes cancer patient blood}

The levels of exosomes in blood have been correlated with tumor development. Logozzi et al. observed an increase in CD63+ exosomes in melanoma patients compared to healthy donors [140]. In a study of lung adenocarcinoma, both the mean exosome and miRNA concentrations were higher in the lung adenocarcinoma compared to the control group [141]. The expression levels of exosomal miR-21 were correlated with advanced tumor stage, positive lymph node status, and metastasis in patients with esophageal squamous cell cancer [142]. In oral cancer, Ren et al. suggested that elevated levels of circulating microparticles were closely correlated with oral squamous cell carcinoma [143]. Using nanoparticle tracking analysis, Ayelet et al. determined that the concentration of exosomes in blood samples from oral cancer patients was higher than in healthy individuals. Additionally, they observed differences in the size distributions of the exosomes and marker expression between the two groups [144]. It is possible that surgery or treatment with cancer therapeutics could decrease the number of exosomes in blood. Indeed, exosomal miRNAs (a panel) decreased in the blood of patients with lung squamous cell carcinoma surgery [145]. Thus, exosome concentrations in blood may help physicians evaluate the results of surgery and detect relapse in cancer patients.

\section{Applications of exosomes in cancer diagnosis and as prognostic markers in patients with solid tumors}

Blood-based tumor markers such as cancer antigen 199 and alpha-fetal protein are widely used in cancer diagnosis. Recently, Melo et al. demonstrated a high degree of specificity in detecting early pancreatic cancer through the use of glypican-1 circulating exosomes as markers [146]. This is just one advantage of exosomes in detecting early-stage cancers. TDEs can reach cells in distant organs and drive genetic alterations [36, 93, 147, 148]. Eichelser et al. observed an increase in circulating exosomal miRNA-373 in receptor-negative breast cancer patients [149]. Additionally, Huang et al. determined that miR-1290 and miR-375 were prognostic markers in castration-resistant prostate cancer [150]. Finally, Matsumura et al. found that the exosomal miR-19a cluster expression level in serum was correlated with recurrence in colorectal cancer [151]. The results of a meta-analysis suggested that plasma miR-21 may be a reliable and noninvasive biomarker for colorectal cancer diagnosis [152]. In addition to circulating exosomes, three fecal microRNA levels were significantly higher in colorectal cancer patients [153].

New technology has been developed to capture circulating exosomes [28], which can serve as tumor markers for personalized diagnostics. The use of exosomes in liquid biopsy is also currently under investigation [154]. However, as Thery et al. noted, the testing will be more reliable and less complex if the contributions of exosomes and exosomal miRNA to cancer progression are elucidated [155]. In addition, circulating tumor cells contribute to cancer metastasis [156]. Therefore, a combination of exosomes and circulating tumor cell detection could improve the precision of cancer diagnosis.

Circulating miRNAs can be (1) passively transported out of cells, (2) actively secreted by membrane vesicles, or (3) actively secreted by complex formation with lipoproteins (e.g. high-density lipoprotein) and RNAbinding proteins (e.g. AGO2 and nucleophosmin 1) [157]. Arroyo et al. hypothesized that circulating miRNAs may not be not restricted to vesicles. Instead, most miRNAs are associated with circulating Ago 2 complexes. Less than $10 \%$ of miRNAs are vesicle-associated, whereas it is possible that $90 \%$ of miRNAs in the circulation are present in a non-membrane bound form (e.g. in a ribonucleoprotein complex) [158]. However, Gallo et al. found that the majority of miRNAs that were detectable in serum and saliva were concentrated in exosomes. The differences in results could be explained by lysis of exosomes during the isolation process [159].

Given the large number of blood cells in circulation, most miRNAs likely exist in non-membrane bound forms. However, there is increasing evidence for the roles of TDEs in the release of intercellular signaling molecules. Considering exosomes typically target specific cells, compare with total circulating RNAs, it may be reasonable to detect exosomal miRNAs in clinical examinations. On the other hand, increases in the levels of specific miRNAs in the circulation may be readily detected in exosomes. This may assist physicians with predicting cancer patient prognosis. Although non-membrane-bound miRNAs are 
stable in the blood, they are still regarded as non-specific by-products of cell activity and death. In addition, the biological functions of miRNAs have not been fully elucidated [160, 161]. Overall, exosomes and exosomal miRNAs in blood may be useful markers of early-stage cancer and may be predictive of prognosis.

\section{Drug delivery}

Exosomes can also be used for drug delivery. The development of nanoformulations has improved the therapeutic efficacy of drugs. Unfortunately, none of the nanotechniques avoid toxicity, and the drugs are typically cleared by the immune system immediately [162]. Exosomes are advantageous in that they can function as both synthetic nanocarriers and as cell-mediated drug delivery vehicles [163]. It is generally difficult to deliver drugs into the brain because of the selectivity of the bloodbrain barrier. However, exosomes are lipid soluble and can easily cross the blood-brain barrier [164]. There are at least three ways that drugs can be loaded into exosomes for delivery: 1) naïve exosomes isolated from parental cells can be loaded ex vivo, 2) parental cells can be loaded with a drug, which is then released in exosomes, or 3) parental cells can be infected/transfected with DNA that encodes therapeutically active compounds, which are then released in exosomes [163]. Batrakova et al. first delivered the enzyme catalase (a large therapeutic protein) to the brain by loading exosomes extracted from immune cells with the enzyme [165]. Importantly, exosomes have the natural ability to home to tumors without eliciting an immune response. Exosome-encapsulated paclitaxel is 50 times more potent against drug-resistant lung cancer tumors [166].

\section{CONCLUSIONS}

There is compelling evidence for the roles of exosomes in cancer. Exosomes are distinct from other EVs. To date, most studies have analyzed mixed EV populations, and not all EV subgroups have been characterized. The formation of exosomes is tightly regulated to ensure content stability and maintain biological activity. Like seeds from soil (primary tumor), exosomes may serve as "Trojan Horses". There are thousands of miRNAs with potential functions in cancer. However, significantly fewer are present in exosomes. The molecular mechanisms underlying the sorting and release of cellular contents into exosomes are not yet clear. Because exosomes comprise an information transduction pathway in cancer, they have the potential to educate and compel other cell types (e.g. immune cells) to build a niche suitable for CTC colonization. An increasing number of clinical tests have been performed to study exosomes, which contain specific miRNAs or surface proteins. It is important to note that TDEs are qualitatively different from those derived from non-cancerous cells. Additional studies are required to distinguish TDEs from exosomes secreted by normal cells. Finally, advances in technology will result in new insights into exosome function and therapeutic potential.

\section{ACKNOWLEDGMENTS}

The work was supported by the National Natural Science Foundation of China (81472666), the Key Projects in the National Science \& Technology Pillar Program during the Twelfth Five-year Plan Period (2014BAI09B07) and the Fundamental Research Funds for the Central Universities (2016FZA7011).

\section{CONFLICTS OF INTEREST}

The authors declare that there are no conflicts of interest.

\section{REFERENCES}

1. Yáñez-Mó M, Siljander PRM, Andreu Z, Bedina Zavec A, Borràs FE, Buzas EI, Buzas K, Casal E, Cappello F, Carvalho J, Colás E, Cordeiro-da Silva A, Fais S, et al. Biological properties of extracellular vesicles and their physiological functions. Journal of Extracellular Vesicles. 2015; 4. doi: 10.3402/jev.v4.27066.

2. Johnstone RM, Adam M, Hammond JR, Orr L, Turbide C. Vesicle formation during reticulocyte maturation. Association of plasma membrane activities with released vesicles (exosomes). J Biol Chem. 1987; 262: 9412-20.

3. Danielson KM, Das S. Extracellular Vesicles in Heart Disease: Excitement for the Future ? Exosomes Microvesicles. 2014; 2. doi: 10.5772/58390.

4. Yelamanchili SV, Lamberty BG, Rennard DA, Morsey BM, Hochfelder CG, Meays BM, Levy E, Fox HS. MiR-21 in Extracellular Vesicles Leads to Neurotoxicity via TLR7 Signaling in SIV Neurological Disease. PLoS Pathog. 2015; 11: e1005032. doi: 10.1371/journal.ppat.1005032.

5. Winkler $\mathrm{CW}$, Taylor $\mathrm{KG}$, Peterson KE. Location is everything: let-7b microRNA and TLR7 signaling results in a painful TRP. Sci Signal. 2014; 7: pe14. doi: 10.1126/ scisignal.2005407.

6. Taylor DD, Gercel-Taylor C. MicroRNA signatures of tumor-derived exosomes as diagnostic biomarkers of ovarian cancer. Gynecol Oncol. 2008; 110: 13-21. doi: 10.1016/j.ygyno.2008.04.033.

7. Théry C, Amigorena S, Raposo G, Clayton A. (2001). Isolation and Characterization of Exosomes from Cell Culture Supernatants and Biological Fluids. Current Protocols in Cell Biology: John Wiley \& Sons, Inc.).

8. Thery C, Amigorena S, Raposo G, Clayton A. Isolation and 
characterization of exosomes from cell culture supernatants and biological fluids. Curr Protoc Cell Biol. 2006; Chapter 3: Unit 3 22. doi: 10.1002/0471143030.cb0322s30.

9. Abramowicz A, Widlak P, Pietrowska M. Proteomic analysis of exosomal cargo: the challenge of high purity vesicle isolation. Mol Biosyst. 2016; 12: 1407-19. doi: 10.1039/c6mb00082g.

10. Van Deun J, Mestdagh P, Sormunen R, Cocquyt V, Vermaelen K, Vandesompele J, Bracke M, De Wever O, Hendrix A. The impact of disparate isolation methods for extracellular vesicles on downstream RNA profiling. J Extracell Vesicles. 2014; 3. doi: 10.3402/jev.v3.24858.

11. Rider MA, Hurwitz SN, Meckes DG, Jr. ExtraPEG: A Polyethylene Glycol-Based Method for Enrichment of Extracellular Vesicles. Sci Rep. 2016; 6: 23978. doi: 10.1038/srep23978.

12. Weng Y, Sui Z, Shan Y, Hu Y, Chen Y, Zhang L, Zhang Y. Effective isolation of exosomes with polyethylene glycol from cell culture supernatant for in-depth proteome profiling. Analyst. 2016. doi: 10.1039/c6an00892e.

13. Paolini L, Zendrini A, Noto GD, Busatto S, Lottini E, Radeghieri A, Dossi A, Caneschi A, Ricotta D, Bergese P. Residual matrix from different separation techniques impacts exosome biological activity. Sci Rep. 2016; 6: 23550. doi: 10.1038/srep23550.

14. Zeringer E, Li M, Barta T, Schageman J, Pedersen KW, Neurauter A, Magdaleno S, Setterquist R, Vlassov AV. Methods for the extraction and RNA profiling of exosomes. World J Methodol. 2013; 3: 11-8. doi: 10.5662/wjm. v3.i1.11.

15. King HW, Michael MZ, Gleadle JM. Hypoxic enhancement of exosome release by breast cancer cells. BMC Cancer. 2012; 12: 421. doi: 10.1186/1471-2407-12-421.

16. Bonafede R, Scambi I, Peroni D, Potrich V, Boschi F, Benati D, Bonetti B, Mariotti R. Exosome derived from murine adipose-derived stromal cells: Neuroprotective effect on in vitro model of amyotrophic lateral sclerosis. Exp Cell Res. 2016; 340: 150-8. doi: 10.1016/j.yexcr.2015.12.009.

17. Lobb RJ, Becker M, Wen SW, Wong CS, Wiegmans AP, Leimgruber A, Moller A. Optimized exosome isolation protocol for cell culture supernatant and human plasma. J Extracell Vesicles. 2015; 4: 27031. doi: 10.3402/jev. $\mathrm{v} 4.27031$.

18. Enderle D, Spiel A, Coticchia CM, Berghoff E, Mueller R, Schlumpberger M, Sprenger-Haussels M, Shaffer JM, Lader E, Skog J, Noerholm M. Characterization of RNA from Exosomes and Other Extracellular Vesicles Isolated by a Novel Spin Column-Based Method. PLoS One. 2015; 10: e0136133. doi: 10.1371/journal.pone.0136133.

19. Xu R, Greening DW, Rai A, Ji H, Simpson RJ. Highlypurified exosomes and shed microvesicles isolated from the human colon cancer cell line LIM1863 by sequential centrifugal ultrafiltration are biochemically and functionally distinct. Methods. 2015. doi: 10.1016/j.ymeth.2015.04.008.
20. Witwer KW, Buzas EI, Bemis LT, Bora A, Lasser C, Lotvall J, Nolte-'t Hoen EN, Piper MG, Sivaraman S, Skog J, Thery C, Wauben MH, Hochberg F. Standardization of sample collection, isolation and analysis methods in extracellular vesicle research. J Extracell Vesicles. 2013; 2. doi: $10.3402 /$ jev.v2i0.20360.

21. Gao W, Chen L, Ma Z, Du Z, Zhao Z, Hu Z, Li Q. Isolation and Phenotypic Characterization of Colorectal Cancer Stem Cells With Organ-Specific Metastatic Potential. Gastroenterology. 2013; 145: 636-46.e5. doi: 10.1053/j. gastro.2013.05.049.

22. Tauro BJ, Greening DW, Mathias RA, Ji H, Mathivanan S, Scott AM, Simpson RJ. Comparison of ultracentrifugation, density gradient separation, and immunoaffinity capture methods for isolating human colon cancer cell line LIM1863-derived exosomes. Methods. 2012; 56: 293-304. doi: 10.1016/j.ymeth.2012.01.002.

23. Verweij FJ, van Eijndhoven MA, Middeldorp J, Pegtel DM. Analysis of viral microRNA exchange via exosomes in vitro and in vivo. Methods Mol Biol. 2013; 1024: 53-68. doi: 10.1007/978-1-62703-453-1_5.

24. Kalra H, Adda CG, Liem M, Ang CS, Mechler A, Simpson RJ, Hulett MD, Mathivanan S. Comparative proteomics evaluation of plasma exosome isolation techniques and assessment of the stability of exosomes in normal human blood plasma. Proteomics. 2013; 13: 3354-64. doi: 10.1002/ pmic.201300282.

25. Yoshioka Y, Kosaka N, Konishi Y, Ohta H, Okamoto H, Sonoda H, Nonaka R, Yamamoto H, Ishii H, Mori M, Furuta K, Nakajima T, Hayashi H, et al. Ultra-sensitive liquid biopsy of circulating extracellular vesicles using ExoScreen. Nat Commun. 2014; 5: 3591. doi: 10.1038/ ncomms4591.

26. Musante L, Tataruch D, Gu D, Benito-Martin A, Calzaferri G, Aherne S, Holthofer H. A simplified method to recover urinary vesicles for clinical applications, and sample banking. Sci Rep. 2014; 4: 7532. doi: 10.1038/srep07532.

27. Lotvall J, Hill AF, Hochberg F, Buzas EI, Di Vizio D, Gardiner C, Gho YS, Kurochkin IV, Mathivanan S, Quesenberry P, Sahoo S, Tahara H, Wauben MH, et al. Minimal experimental requirements for definition of extracellular vesicles and their functions: a position statement from the International Society for Extracellular Vesicles. J Extracell Vesicles. 2014; 3: 26913. doi: 10.3402/ jev.v3.26913.

28. Im H, Shao H, Weissleder R, Castro CM, Lee H. Nanoplasmonic exosome diagnostics. Expert Rev Mol Diagn. 2015; 15: 725-33. doi: 10.1586/14737159.2015.1041378.

29. Yoon J, Jo W, Jeong D, Kim J, Jeong H, Park J. Generation of nanovesicles with sliced cellular membrane fragments for exogenous material delivery. Biomaterials. 2015; 59: 12-20. doi: 10.1016/j.biomaterials.2015.04.028.

30. Taller D, Richards K, Slouka Z, Senapati S, Hill R, Go DB, Chang HC. On-chip surface acoustic wave lysis and ionexchange nanomembrane detection of exosomal RNA for 
pancreatic cancer study and diagnosis. Lab Chip. 2015; 15: 1656-66. doi: 10.1039/c5lc00036j.

31. Lee K, Shao H, Weissleder R, Lee H. Acoustic purification of extracellular microvesicles. ACS Nano. 2015; 9: 2321-7. doi: 10.1021/nn506538f.

32. Yu B, Zhang X, Li X. Exosomes derived from mesenchymal stem cells. Int J Mol Sci. 2014; 15: 4142-57. doi: 10.3390/ ijms 15034142 .

33. Sokolova V, Ludwig AK, Hornung S, Rotan O, Horn PA, Epple M, Giebel B. Characterisation of exosomes derived from human cells by nanoparticle tracking analysis and scanning electron microscopy. Colloids Surf B Biointerfaces. 2011; 87: 146-50. doi: 10.1016/j. colsurfb.2011.05.013.

34. Malik ZA, Kott KS, Poe AJ, Kuo T, Chen L, Ferrara KW, Knowlton AA. Cardiac myocyte exosomes: stability, HSP60, and proteomics. Am J Physiol Heart Circ Physiol. 2013; 304: H954-65. doi: 10.1152/ajpheart.00835.2012.

35. Valadi H, Ekstrom K, Bossios A, Sjostrand M, Lee JJ, Lotvall JO. Exosome-mediated transfer of mRNAs and microRNAs is a novel mechanism of genetic exchange between cells. Nat Cell Biol. 2007; 9: 654-9. doi: 10.1038/ ncb1596.

36. Skog J, Wurdinger T, van Rijn S, Meijer DH, Gainche L, Sena-Esteves M, Curry WT, Jr., Carter BS, Krichevsky AM, Breakefield XO. Glioblastoma microvesicles transport RNA and proteins that promote tumour growth and provide diagnostic biomarkers. Nat Cell Biol. 2008; 10: 1470-6. doi: 10.1038/ncb1800.

37. Guescini M, Genedani S, Stocchi V, Agnati LF. Astrocytes and Glioblastoma cells release exosomes carrying mtDNA. J Neural Transm (Vienna). 2010; 117: 1-4. doi: 10.1007/ s00702-009-0288-8.

38. Balaj L, Lessard R, Dai L, Cho YJ, Pomeroy SL, Breakefield $\mathrm{XO}$, Skog J. Tumour microvesicles contain retrotransposon elements and amplified oncogene sequences. Nat Commun. 2011; 2: 180. doi: 10.1038/ncomms1180.

39. Thakur BK, Zhang H, Becker A, Matei I, Huang Y, CostaSilva B, Zheng Y, Hoshino A, Brazier H, Xiang J, Williams C, Rodriguez-Barrueco R, Silva JM, et al. Double-stranded DNA in exosomes: a novel biomarker in cancer detection. Cell Res. 2014; 24: 766-9. doi: 10.1038/cr.2014.44.

40. Li Y, Zheng Q, Bao C, Li S, Guo W, Zhao J, Chen D, Gu J, He X, Huang S. Circular RNA is enriched and stable in exosomes: a promising biomarker for cancer diagnosis. Cell Res. 2015; 3: 82 .

41. Zomer A, Maynard C, Verweij FJ, Kamermans A, Schafer R, Beerling E, Schiffelers RM, de Wit E, Berenguer J, Ellenbroek SI, Wurdinger T, Pegtel DM, van Rheenen J. In Vivo imaging reveals extracellular vesicle-mediated phenocopying of metastatic behavior. Cell. 2015; 161: 1046-57. doi: 10.1016/j.cell.2015.04.042.

42. Melo SA, Sugimoto H, O'Connell JT, Kato N, Villanueva A, Vidal A, Qiu L, Vitkin E, Perelman LT, Melo CA, Lucci
A, Ivan C, Calin GA, et al. Cancer exosomes perform cell-independent microRNA biogenesis and promote tumorigenesis. Cancer Cell. 2014; 26: 707-21. doi: 10.1016/j.ccell.2014.09.005.

43. Singh R, Pochampally R, Watabe K, Lu Z, Mo YY. Exosome-mediated transfer of miR-10b promotes cell invasion in breast cancer. Mol Cancer. 2014; 13: 256. doi: 10.1186/1476-4598-13-256.

44. Neerincx M, Sie DL, van de Wiel MA, van Grieken NC, Burggraaf JD, Dekker H, Eijk PP, Ylstra B, Verhoef C, Meijer GA, Buffart TE, Verheul HM. MiR expression profiles of paired primary colorectal cancer and metastases by next-generation sequencing. Oncogenesis. 2015; 4: e170. doi: 10.1038/oncsis.2015.29.

45. Ji H, Chen M, Greening DW, He W, Rai A, Zhang W, Simpson RJ. Deep sequencing of RNA from three different extracellular vesicle (EV) subtypes released from the human LIM1863 colon cancer cell line uncovers distinct miRNAenrichment signatures. PLoS One. 2014; 9: e110314. doi: 10.1371/journal.pone.0110314.

46. Cha DJ, Franklin JL, Dou Y, Liu Q, Higginbotham JN, Demory Beckler M, Weaver AM, Vickers K, Prasad N, Levy S, Zhang B, Coffey RJ, Patton JG. KRAS-dependent sorting of miRNA to exosomes. Elife. 2015; 4: e07197. doi: 10.7554/eLife.07197.

47. Ostrowski M, Carmo NB, Krumeich S, Fanget I, Raposo G, Savina A, Moita CF, Schauer K, Hume AN, Freitas RP, Goud B, Benaroch P, Hacohen N, et al. Rab27a and Rab27b control different steps of the exosome secretion pathway. Nat Cell Biol. 2010; 12: 19-30; sup pp 1-13. doi: 10.1038/ ncb2000.

48. Zhou W, Fong MY, Min Y, Somlo G, Liu L, Palomares MR, Yu Y, Chow A, O'Connor ST, Chin AR, Yen Y, Wang Y, Marcusson EG, et al. Cancer-secreted miR-105 destroys vascular endothelial barriers to promote metastasis. Cancer Cell. 2014; 25: 501-15. doi: 10.1016/j.ccr.2014.03.007.

49. Peinado H, Lavotshkin S, Lyden D. The secreted factors responsible for pre-metastatic niche formation: old sayings and new thoughts. Semin Cancer Biol. 2011; 21: 139-46. doi: 10.1016/j.semcancer.2011.01.002.

50. Peinado H, Aleckovic M, Lavotshkin S, Matei I, CostaSilva B, Moreno-Bueno G, Hergueta-Redondo M, Williams C, Garcia-Santos G, Ghajar C, Nitadori-Hoshino A, Hoffman C, Badal K, et al. Melanoma exosomes educate bone marrow progenitor cells toward a pro-metastatic phenotype through MET. Nat Med. 2012; 18: 883-91. doi: 10.1038/nm.2753.

51. Costa-Silva B, Aiello NM, Ocean AJ, Singh S, Zhang H, Thakur BK, Becker A, Hoshino A, Mark MT, Molina H, Xiang J, Zhang T, Theilen TM, et al. Pancreatic cancer exosomes initiate pre-metastatic niche formation in the liver. Nat Cell Biol. 2015. doi: 10.1038/ncb3169.

52. Hoshino A, Costa-Silva B, Shen TL, Rodrigues G, Hashimoto A, Tesic Mark M, Molina H, Kohsaka S, Di Giannatale A, Ceder S, Singh S, Williams C, Soplop N, 
et al. Tumour exosome integrins determine organotropic metastasis. Nature. 2015; 527: 329-35. doi: 10.1038/ nature 15756.

53. Grange C, Tapparo M, Collino F, Vitillo L, Damasco C, Deregibus MC, Tetta C, Bussolati B, Camussi G. Microvesicles released from human renal cancer stem cells stimulate angiogenesis and formation of lung premetastatic niche. Cancer Res. 2011; 71: 5346-56. doi: 10.1158/00085472.can-11-0241.

54. Tkach M, Thery C. Communication by Extracellular Vesicles: Where We Are and Where We Need to Go. Cell. 2016; 164: 1226-32. doi: 10.1016/j.cell.2016.01.043.

55. Zhang L, Zhang S, Yao J, Lowery FJ, Zhang Q, Huang WC, Li P, Li M, Wang X, Zhang C, Wang H, Ellis K, Cheerathodi $\mathrm{M}$, et al. Microenvironment-induced PTEN loss by exosomal microRNA primes brain metastasis outgrowth. Nature. 2015. doi: 10.1038/nature15376.

56. Schey KL, Luther JM, Rose KL. Proteomics characterization of exosome cargo. Methods. 2015. doi: 10.1016/j.ymeth.2015.03.018.

57. Jeppesen DK, Nawrocki A, Jensen SG, Thorsen K, Whitehead B, Howard KA, Dyrskjot L, Orntoft TF, Larsen MR, Ostenfeld MS. Quantitative proteomics of fractionated membrane and lumen exosome proteins from isogenic metastatic and nonmetastatic bladder cancer cells reveal differential expression of EMT factors. Proteomics. 2014; 14: 699-712. doi: 10.1002/pmic.201300452.

58. Epple LM, Griffiths SG, Dechkovskaia AM, Dusto NL, White J, Ouellette RJ, Anchordoquy TJ, Bemis LT, Graner MW. Medulloblastoma exosome proteomics yield functional roles for extracellular vesicles. PLoS One. 2012; 7: e42064. doi: 10.1371/journal.pone.0042064.

59. Choi DS, Choi DY, Hong BS, Jang SC, Kim DK, Lee J, Kim YK, Kim KP, Gho YS. Quantitative proteomics of extracellular vesicles derived from human primary and metastatic colorectal cancer cells. J Extracell Vesicles. 2012; 1. doi: 10.3402/jev.v1i0.18704.

60. Kalra H, Simpson RJ, Ji H, Aikawa E, Altevogt P, Askenase P, Bond VC, Borras FE, Breakefield X, Budnik V, Buzas E, Camussi G, Clayton A, et al. Vesiclepedia: a compendium for extracellular vesicles with continuous community annotation. PLoS Biol. 2012; 10: e1001450. doi: 10.1371/ journal.pbio.1001450.

61. Kim DK, Kang B, Kim OY, Choi DS, Lee J, Kim SR, Go G, Yoon YJ, Kim JH, Jang SC, Park KS, Choi EJ, Kim KP, et al. EVpedia: an integrated database of high-throughput data for systemic analyses of extracellular vesicles. J Extracell Vesicles. 2013; 2. doi: 10.3402/jev.v2i0.20384.

62. Kim DK, Lee J, Kim SR, Choi DS, Yoon YJ, Kim JH, Go G, Nhung D, Hong K, Jang SC, Kim SH, Park KS, Kim OY, et al. EVpedia: a community web portal for extracellular vesicles research. Bioinformatics. 2015; 31: 933-9. doi: 10.1093/bioinformatics/btu741.
63. Simpson RJ, Kalra H, Mathivanan S. ExoCarta as a resource for exosomal research. J Extracell Vesicles. 2012; 1. doi: 10.3402/jev.v1i0.18374.

64. Ung TH, Madsen HJ, Hellwinkel JE, Lencioni AM, Graner MW. Exosome proteomics reveals transcriptional regulator proteins with potential to mediate downstream pathways. Cancer Sci. 2014; 105: 1384-92. doi: 10.1111/cas.12534.

65. Lee JE, Moon PG, Cho YE, Kim YB, Kim IS, Park H, Baek MC. Identification of EDIL3 on extracellular vesicles involved in breast cancer cell invasion. J Proteomics. 2016; 131: 17-28. doi: 10.1016/j.jprot.2015.10.005.

66. Kosaka N, Iguchi H, Hagiwara K, Yoshioka Y, Takeshita F, Ochiya T. Neutral Sphingomyelinase 2 (nSMase2)dependent Exosomal Transfer of Angiogenic MicroRNAs Regulate Cancer Cell Metastasis. Journal of Biological Chemistry. 2013; 288: 10849-59. doi: 10.1074/jbc. M112.446831.

67. Bovy N, Blomme B, Freres P, Dederen S, Nivelles O, Lion M, Carnet O, Martial JA, Noel A, Thiry M, Jerusalem G, Josse C, Bours V, et al. Endothelial exosomes contribute to the antitumor response during breast cancer neoadjuvant chemotherapy via microRNA transfer. Oncotarget. 2015; 6: 10253-66. doi: 10.18632/oncotarget.3520.

68. Jang JY, Lee JK, Jeon YK, Kim CW. Exosome derived from epigallocatechin gallate treated breast cancer cells suppresses tumor growth by inhibiting tumor-associated macrophage infiltration and M2 polarization. BMC Cancer. 2013; 13: 421. doi: 10.1186/1471-2407-13-421.

69. Lee JK, Park SR, Jung BK, Jeon YK, Lee YS, Kim MK, Kim YG, Jang JY, Kim CW. Exosomes derived from mesenchymal stem cells suppress angiogenesis by downregulating VEGF expression in breast cancer cells. PLoS One. 2013; 8: e84256. doi: 10.1371/journal.pone.0084256.

70. Fong MY, Zhou W, Liu L, Alontaga AY, Chandra M, Ashby J, Chow A, O'Connor ST, Li S, Chin AR, Somlo G, Palomares M, Li Z, et al. Breast-cancer-secreted miR-122 reprograms glucose metabolism in premetastatic niche to promote metastasis. Nat Cell Biol. 2015; 17: 183-94. doi: 10.1038/ncb3094.

71. Gernapudi R, Yao Y, Zhang Y, Wolfson B, Roy S, Duru N, Eades G, Yang P, Zhou Q. Targeting exosomes from preadipocytes inhibits preadipocyte to cancer stem cell signaling in early-stage breast cancer. Breast Cancer Res Treat. 2015; 150: 685-95. doi: 10.1007/s10549-015-3326-2.

72. Ono M, Kosaka N, Tominaga N, Yoshioka Y, Takeshita F, Takahashi RU, Yoshida M, Tsuda H, Tamura K, Ochiya $\mathrm{T}$. Exosomes from bone marrow mesenchymal stem cells contain a microRNA that promotes dormancy in metastatic breast cancer cells. Sci Signal. 2014; 7: ra63. doi: 10.1126/ scisignal.2005231.

73. Lim PK, Bliss SA, Patel SA, Taborga M, Dave MA, Gregory LA, Greco SJ, Bryan M, Patel PS, Rameshwar P. Gap junction-mediated import of microRNA from bone marrow stromal cells can elicit cell cycle quiescence in 
breast cancer cells. Cancer Res. 2011; 71: 1550-60. doi: 10.1158/0008-5472.CAN-10-2372.

74. O'Brien K, Lowry MC, Corcoran C, Martinez VG, Daly M, Rani S, Gallagher WM, Radomski MW, MacLeod RA, O'Driscoll L. miR-134 in extracellular vesicles reduces triple-negative breast cancer aggression and increases drug sensitivity. Oncotarget. 2015; 6: 32774-89. doi: 10.18632/ oncotarget.5192.

75. Wei Y, Lai X, Yu S, Chen S, Ma Y, Zhang Y, Li H, Zhu X, Yao L, Zhang J. Exosomal miR-221/222 enhances tamoxifen resistance in recipient ER-positive breast cancer cells. Breast Cancer Res Treat. 2014; 147: 423-31. doi: 10.1007/s10549-014-3037-0.

76. Yang M, Chen J, Su F, Yu B, Su F, Lin L, Liu Y, Huang JD, Song E. Microvesicles secreted by macrophages shuttle invasion-potentiating microRNAs into breast cancer cells. Mol Cancer. 2011; 10: 117. doi: 10.1186/1476-4598-10117.

77. Lee HK, Finniss S, Cazacu S, Bucris E, Ziv-Av A, Xiang C, Bobbitt K, Rempel SA, Hasselbach L, Mikkelsen T, Slavin S, Brodie C. Mesenchymal stem cells deliver synthetic microRNA mimics to glioma cells and glioma stem cells and inhibit their cell migration and self-renewal. Oncotarget. 2013; 4: 346-61. doi: 10.18632/oncotarget.868.

78. Baglio SR, Rooijers K, Koppers-Lalic D, Verweij FJ, Perez Lanzon M, Zini N, Naaijkens B, Perut F, Niessen HW, Baldini N, Pegtel DM. Human bone marrow- and adiposemesenchymal stem cells secrete exosomes enriched in distinctive miRNA and tRNA species. Stem Cell Res Ther. 2015; 6: 127. doi: 10.1186/s13287-015-0116-Z.

79. Alexander M, Hu R, Runtsch MC, Kagele DA, Mosbruger TL, Tolmachova T, Seabra MC, Round JL, Ward DM, O'Connell RM. Exosome-delivered microRNAs modulate the inflammatory response to endotoxin. Nat Commun. 2015; 6: 7321. doi: 10.1038/ncomms8321.

80. Xiao H, Lasser C, Shelke GV, Wang J, Radinger M, Lunavat TR, Malmhall C, Lin LH, Li J, Li L, Lotvall J. Mast cell exosomes promote lung adenocarcinoma cell proliferation - role of KIT-stem cell factor signaling. Cell Commun Signal. 2014; 12: 64. doi: 10.1186/s12964-0140064-8.

81. Valencia K, Luis-Ravelo D, Bovy N, Anton I, MartinezCanarias S, Zandueta C, Ormazabal C, Struman I, Tabruyn S, Rebmann V, De Las Rivas J, Guruceaga E, Bandres E, et al. miRNA cargo within exosome-like vesicle transfer influences metastatic bone colonization. Mol Oncol. 2014; 8: 689-703. doi: 10.1016/j.molonc.2014.01.012.

82. Liu Y, Luo F, Wang B, Li H, Xu Y, Liu X, Shi L, Lu X, $\mathrm{Xu} \mathrm{W,} \mathrm{Lu} \mathrm{L,} \mathrm{Qin} \mathrm{Y,} \mathrm{Xiang} \mathrm{Q,} \mathrm{Liu} \mathrm{Q.} \mathrm{STAT3-regulated}$ exosomal miR-21 promotes angiogenesis and is involved in neoplastic processes of transformed human bronchial epithelial cells. Cancer Lett. 2016; 370: 125-35. doi: 10.1016/j.canlet.2015.10.011.

83. Cui H, Seubert B, Stahl E, Dietz H, Reuning U, MorenoLeon L, Ilie M, Hofman P, Nagase H, Mari B, Kruger A.
Tissue inhibitor of metalloproteinases-1 induces a protumourigenic increase of miR-210 in lung adenocarcinoma cells and their exosomes. Oncogene. 2015; 34: 3640-50. doi: 10.1038/onc.2014.300.

84. Fabbri M, Paone A, Calore F, Galli R, Gaudio E, Santhanam R, Lovat F, Fadda P, Mao C, Nuovo GJ, Zanesi $\mathrm{N}$, Crawford M, Ozer GH, et al. MicroRNAs bind to Toll-like receptors to induce prometastatic inflammatory response. Proc Natl Acad Sci U S A. 2012; 109: E2110-6. doi: 10.1073/pnas.1209414109.

85. Corcoran C, Rani S, O'Driscoll L. miR-34a is an intracellular and exosomal predictive biomarker for response to docetaxel with clinical relevance to prostate cancer progression. Prostate. 2014; 74: 1320-34. doi: 10.1002/pros.22848.

86. Kim J, Morley S, Le M, Bedoret D, Umetsu DT, Di Vizio D, Freeman MR. Enhanced shedding of extracellular vesicles from amoeboid prostate cancer cells: potential effects on the tumor microenvironment. Cancer Biol Ther. 2014; 15: 409-18. doi: 10.4161/cbt.27627.

87. Xu XD, Wu XH, Fan YR, Tan B, Quan Z, Luo CL. Exosome-derived microRNA-29c induces apoptosis of BIU-87 cells by down regulating BCL-2 and MCL-1. Asian Pac J Cancer Prev. 2014; 15: 3471-6.

88. Xiao D, Ohlendorf J, Chen Y, Taylor DD, Rai SN, Waigel $\mathrm{S}$, Zacharias W, Hao H, McMasters KM. Identifying mRNA, microRNA and protein profiles of melanoma exosomes. PLoS One. 2012; 7: e46874. doi: 10.1371/ journal.pone.0046874.

89. Felicetti F, De Feo A, Coscia C, Puglisi R, Pedini F, Pasquini L, Bellenghi M, Errico MC, Pagani E, Care A. Exosome-mediated transfer of miR-222 is sufficient to increase tumor malignancy in melanoma. J Transl Med. 2016; 14: 56. doi: 10.1186/s12967-016-0811-2.

90. Chiba M, Kimura M, Asari S. Exosomes secreted from human colorectal cancer cell lines contain mRNAs, microRNAs and natural antisense RNAs, that can transfer into the human hepatoma HepG2 and lung cancer A549 cell lines. Oncol Rep. 2012; 28: 1551-8. doi: 10.3892/ or.2012.1967.

91. Wang JJ, Wang ZY, Chen R, Xiong J, Yao YL, Wu JH, Li GX. Macrophage-secreted Exosomes Delivering miRNA-21 Inhibitor can Regulate BGC-823 Cell Proliferation. Asian Pac J Cancer Prev. 2015; 16: 4203-9.

92. Wang M, Zhao C, Shi H, Zhang B, Zhang L, Zhang X, Wang S, Wu X, Yang T, Huang F, Cai J, Zhu Q, Zhu W, et al. Deregulated microRNAs in gastric cancer tissuederived mesenchymal stem cells: novel biomarkers and a mechanism for gastric cancer. Br J Cancer. 2014; 110: 1199-210. doi: 10.1038/bjc.2014.14.

93. Ohshima K, Inoue K, Fujiwara A, Hatakeyama K, Kanto K, Watanabe Y, Muramatsu K, Fukuda Y, Ogura S, Yamaguchi K, Mochizuki T. Let-7 microRNA family is selectively secreted into the extracellular environment via exosomes in a metastatic gastric cancer cell line. PLoS One. 
2010; 5: e13247. doi: 10.1371/journal.pone.0013247.

94. Dadras SS, Tokuhisa M, Ichikawa Y, Kosaka N, Ochiya T, Yashiro M, Hirakawa K, Kosaka T, Makino H, Akiyama H, Kunisaki C, Endo I. Exosomal miRNAs from Peritoneum Lavage Fluid as Potential Prognostic Biomarkers of Peritoneal Metastasis in Gastric Cancer. Plos One. 2015; 10: e0130472. doi: 10.1371/journal.pone.0130472.

95. Aucher A, Rudnicka D, Davis DM. MicroRNAs transfer from human macrophages to hepato-carcinoma cells and inhibit proliferation. J Immunol. 2013; 191: 6250-60. doi: 10.4049/jimmunol.1301728.

96. Basu S, Bhattacharyya SN. Insulin-like growth factor-1 prevents miR-122 production in neighbouring cells to curtail its intercellular transfer to ensure proliferation of human hepatoma cells. Nucleic Acids Res. 2014; 42: 717085. doi: 10.1093/nar/gku346.

97. Kogure T, Lin WL, Yan IK, Braconi C, Patel T. Intercellular nanovesicle-mediated microRNA transfer: a mechanism of environmental modulation of hepatocellular cancer cell growth. Hepatology. 2011; 54: 1237-48. doi: 10.1002/ hep. 24504.

98. Haga H, Yan IK, Takahashi K, Wood J, Zubair A, Patel T. Tumour cell-derived extracellular vesicles interact with mesenchymal stem cells to modulate the microenvironment and enhance cholangiocarcinoma growth. J Extracell Vesicles. 2015; 4: 24900. doi: 10.3402/jev.v4.24900.

99. Tadokoro H, Umezu T, Ohyashiki K, Hirano T, Ohyashiki JH. Exosomes derived from hypoxic leukemia cells enhance tube formation in endothelial cells. J Biol Chem. 2013; 288: 34343-51. doi: 10.1074/jbc.M113.480822.

100. Taverna S, Amodeo V, Saieva L, Russo A, Giallombardo M, De Leo G, Alessandro R. Exosomal shuttling of miR126 in endothelial cells modulates adhesive and migratory abilities of chronic myelogenous leukemia cells. Mol Cancer. 2014; 13: 169. doi: 10.1186/1476-4598-13-169.

101. Farahani M, Rubbi C, Liu L, Slupsky JR, Kalakonda N. CLL Exosomes Modulate the Transcriptome and Behaviour of Recipient Stromal Cells and Are Selectively Enriched in miR-202-3p. PLoS One. 2015; 10: e0141429. doi: 10.1371/ journal.pone.0141429.

102. Umezu T, Ohyashiki K, Kuroda M, Ohyashiki JH. Leukemia cell to endothelial cell communication via exosomal miRNAs. Oncogene. 2013; 32: 2747-55. doi: 10.1038/onc.2012.295.

103. Paggetti J, Haderk F, Seiffert M, Janji B, Distler U, Ammerlaan W, Kim YJ, Adam J, Lichter P, Solary E, Berchem G, Moussay E. Exosomes released by chronic lymphocytic leukemia cells induce the transition of stromal cells into cancer-associated fibroblasts. Blood. 2015; 126: 1106-17. doi: 10.1182/blood-2014-12-618025.

104. Umezu T, Tadokoro H, Azuma K, Yoshizawa S, Ohyashiki K, Ohyashiki JH. Exosomal miR-135b shed from hypoxic multiple myeloma cells enhances angiogenesis by targeting factor-inhibiting HIF-1. Blood. 2014; 124: 3748-57. doi: 10.1182/blood-2014-05-576116.

105. Challagundla KB, Wise PM, Neviani P, Chava H, Murtadha M, Xu T, Kennedy R, Ivan C, Zhang X, Vannini I, Fanini F, Amadori D, Calin GA, et al. Exosome-mediated transfer of microRNAs within the tumor microenvironment and neuroblastoma resistance to chemotherapy. J Natl Cancer Inst. 2015; 107. doi: 10.1093/jnci/djv135.

106. Kobayashi M, Salomon C, Tapia J, Illanes SE, Mitchell $\mathrm{MD}$, Rice GE. Ovarian cancer cell invasiveness is associated with discordant exosomal sequestration of Let7 miRNA and miR-200. J Transl Med. 2014; 12: 4. doi: 10.1186/1479-5876-12-4.

107. Pink RC, Samuel P, Massa D, Caley DP, Brooks SA, Carter DR. The passenger strand, miR-21-3p, plays a role in mediating cisplatin resistance in ovarian cancer cells. Gynecol Oncol. 2015; 137: 143-51. doi: 10.1016/j. ygyno.2014.12.042.

108. Yi H, Ye J, Yang XM, Zhang LW, Zhang ZG, Chen YP. High-grade ovarian cancer secreting effective exosomes in tumor angiogenesis. Int J Clin Exp Pathol. 2015; 8: 506270.

109. Ye SB, Li ZL, Luo DH, Huang BJ, Chen YS, Zhang XS, Cui J, Zeng YX, Li J. Tumor-derived exosomes promote tumor progression and T-cell dysfunction through the regulation of enriched exosomal microRNAs in human nasopharyngeal carcinoma. Oncotarget. 2014; 5: 5439-52. doi: 10.18632/oncotarget.2118.

110. Thery C, Regnault A, Garin J, Wolfers J, Zitvogel L, Ricciardi-Castagnoli P, Raposo G, Amigorena S. Molecular characterization of dendritic cell-derived exosomes. Selective accumulation of the heat shock protein hsc73. J Cell Biol. 1999; 147: 599-610.

111. Andre F, Schartz NE, Chaput N, Flament C, Raposo G, Amigorena S, Angevin E, Zitvogel L. Tumor-derived exosomes: a new source of tumor rejection antigens. Vaccine. 2002; 20 Suppl 4: A28-31.

112. Zeelenberg IS, Ostrowski M, Krumeich S, Bobrie A, Jancic C, Boissonnas A, Delcayre A, Le Pecq JB, Combadiere B, Amigorena S, Thery C. Targeting tumor antigens to secreted membrane vesicles in vivo induces efficient antitumor immune responses. Cancer Res. 2008; 68: 122835. doi: 10.1158/0008-5472.can-07-3163.

113. Zitvogel L, Regnault A, Lozier A, Wolfers J, Flament C, Tenza D, Ricciardi-Castagnoli P, Raposo G, Amigorena S. Eradication of established murine tumors using a novel cellfree vaccine: dendritic cell-derived exosomes. Nat Med. 1998; 4: 594-600.

114. Hsu DH, Paz P, Villaflor G, Rivas A, Mehta-Damani A, Angevin E, Zitvogel L, Le Pecq JB. Exosomes as a tumor vaccine: enhancing potency through direct loading of antigenic peptides. J Immunother. 2003; 26: 440-50.

115. Chaput N, Flament C, Viaud S, Taieb J, Roux S, Spatz A, Andre F, LePecq JB, Boussac M, Garin J, Amigorena S, Thery C, Zitvogel L. Dendritic cell derived-exosomes: 
biology and clinical implementations. J Leukoc Biol. 2006; 80: 471-8. doi: 10.1189/jlb.0206094.

116. Viaud S, Thery C, Ploix S, Tursz T, Lapierre V, Lantz O, Zitvogel L, Chaput N. Dendritic cell-derived exosomes for cancer immunotherapy: what's next? Cancer Res. 2010; 70: 1281-5. doi: 10.1158/0008-5472.can-09-3276.

117. Escudier B, Dorval T, Chaput N, Andre F, Caby MP, Novault S, Flament C, Leboulaire C, Borg C, Amigorena S, Boccaccio C, Bonnerot C, Dhellin O, et al. Vaccination of metastatic melanoma patients with autologous dendritic cell (DC) derived-exosomes: results of thefirst phase I clinical trial. J Transl Med. 2005; 3: 10. doi: 10.1186/1479-5876-310.

118. Azmi AS, Bao B, Sarkar FH. Exosomes in cancer development, metastasis, and drug resistance: a comprehensive review. Cancer Metastasis Rev. 2013; 32: 623-42. doi: 10.1007/s10555-013-9441-9.

119. Andreola G, Rivoltini L, Castelli C, Huber V, Perego P, Deho P, Squarcina P, Accornero P, Lozupone F, Lugini L, Stringaro A, Molinari A, Arancia G, et al. Induction of lymphocyte apoptosis by tumor cell secretion of FasLbearing microvesicles. J Exp Med. 2002; 195: 1303-16.

120. Huber V, Fais S, Iero M, Lugini L, Canese P, Squarcina P, Zaccheddu A, Colone M, Arancia G, Gentile M, Seregni E, Valenti R, Ballabio G, et al. Human colorectal cancer cells induce T-cell death through release of proapoptotic microvesicles: role in immune escape. Gastroenterology. 2005; 128: 1796-804. doi:

121. Klibi J, Niki T, Riedel A, Pioche-Durieu C, Souquere S, Rubinstein E, Le Moulec S, Guigay J, Hirashima M, Guemira F, Adhikary D, Mautner J, Busson P. Blood diffusion and Th1-suppressive effects of galectin-9containing exosomes released by Epstein-Barr virusinfected nasopharyngeal carcinoma cells. Blood. 2009; 113: 1957-66. doi: 10.1182/blood-2008-02-142596.

122. Taylor DD, Gercel-Taylor C, Lyons KS, Stanson J, Whiteside TL. T-cell apoptosis and suppression of T-cell receptor/CD3-zeta by Fas ligand-containing membrane vesicles shed from ovarian tumors. Clin Cancer Res. 2003; 9: 5113-9.

123. Valenti R, Huber V, Filipazzi P, Pilla L, Sovena G, Villa A, Corbelli A, Fais S, Parmiani G, Rivoltini L. Human tumor-released microvesicles promote the differentiation of myeloid cells with transforming growth factor-betamediated suppressive activity on T lymphocytes. Cancer Res. 2006; 66: 9290-8. doi: 10.1158/0008-5472.can-061819.

124. Xiang X, Liu Y, Zhuang X, Zhang S, Michalek S, Taylor DD, Grizzle W, Zhang HG. TLR2-mediated expansion of MDSCs is dependent on the source of tumor exosomes. Am J Pathol. 2010; 177: 1606-10. doi: 10.2353/ ajpath.2010.100245.

125. Chalmin F, Ladoire S, Mignot G, Vincent J, Bruchard
M, Remy-Martin JP, Boireau W, Rouleau A, Simon B, Lanneau D, De Thonel A, Multhoff G, Hamman A, et al. Membrane-associated Hsp72 from tumor-derived exosomes mediates STAT3-dependent immunosuppressive function of mouse and human myeloid-derived suppressor cells. J Clin Invest. 2010; 120: 457-71. doi: 10.1172/jci40483.

126. Liu Y, Xiang X, Zhuang X, Zhang S, Liu C, Cheng Z, Michalek S, Grizzle W, Zhang HG. Contribution of MyD88 to the tumor exosome-mediated induction of myeloid derived suppressor cells. Am J Pathol. 2010; 176: 2490-9. doi: 10.2353/ajpath.2010.090777.

127. Yang C, Ruffner MA, Kim SH, Robbins PD. Plasmaderived MHC class II+ exosomes from tumor-bearing mice suppress tumor antigen-specific immune responses. Eur J Immunol. 2012; 42: 1778-84. doi: 10.1002/eji.201141978.

128. Filipazzi P, Burdek M, Villa A, Rivoltini L, Huber V. Recent advances on the role of tumor exosomes in immunosuppression and disease progression. Semin Cancer Biol. 2012; 22: 342-9. doi: 10.1016/j. semcancer.2012.02.005.

129. Gabrilovich DI, Ostrand-Rosenberg S, Bronte V. Coordinated regulation of myeloid cells by tumours. Nat Rev Immunol. 2012; 12: 253-68. doi: 10.1038/nri3175.

130. Baniyash M. Chronic inflammation, immunosuppression and cancer: new insights and outlook. Semin Cancer Biol. 2006; 16: 80-8. doi: 10.1016/j.semcancer.2005.12.002.

131. Ostrand-Rosenberg S, Sinha P. Myeloid-derived suppressor cells: linking inflammation and cancer. J Immunol. 2009; 182: 4499-506. doi: 10.4049/jimmunol.0802740.

132. Chornoguz O, Grmai L, Sinha P, Artemenko KA, Zubarev RA, Ostrand-Rosenberg S. Proteomic pathway analysis reveals inflammation increases myeloid-derived suppressor cell resistance to apoptosis. Mol Cell Proteomics. 2011; 10: M110 002980. doi: 10.1074/mcp.M110.002980.

133. Taylor DD, Gercel-Taylor C. Exosomes/microvesicles: mediators of cancer-associated immunosuppressive microenvironments. Semin Immunopathol. 2011; 33: 44154. doi: 10.1007/s00281-010-0234-8.

134. Condamine T, Gabrilovich DI. Molecular mechanisms regulating myeloid-derived suppressor cell differentiation and function. Trends Immunol. 2011; 32: 19-25. doi: 10.1016/j.it.2010.10.002.

135. Serafini P, Mgebroff S, Noonan K, Borrello I. Myeloidderived suppressor cells promote cross-tolerance in B-cell lymphoma by expanding regulatory $\mathrm{T}$ cells. Cancer Res. 2008; 68: 5439-49. doi: 10.1158/0008-5472.can-07-6621.

136. Pan PY, Ma G, Weber KJ, Ozao-Choy J, Wang G, Yin B, Divino CM, Chen SH. Immune stimulatory receptor CD40 is required for $\mathrm{T}$-cell suppression and $\mathrm{T}$ regulatory cell activation mediated by myeloid-derived suppressor cells in cancer. Cancer Res. 2010; 70: 99-108. doi: 10.1158/00085472.can-09-1882.

137. Rath T, Stockle J, Roderfeld M, Tschuschner A, Graf J, 
Roeb E. Matrix metalloproteinase-13 is regulated by tolllike receptor-9 in colorectal cancer cells and mediates cellular migration. Oncol Lett. 2011; 2: 483-8. doi: 10.3892/ ol.2011.276.

138. Wieckowski EU, Visus C, Szajnik M, Szczepanski MJ, Storkus WJ, Whiteside TL. Tumor-derived microvesicles promote regulatory $\mathrm{T}$ cell expansion and induce apoptosis in tumor-reactive activated CD8+ T lymphocytes. J Immunol. 2009; 183: 3720-30. doi: 10.4049/jimmunol.0900970.

139. Szajnik M, Czystowska M, Szczepanski MJ, Mandapathil M, Whiteside TL. Tumor-derived microvesicles induce, expand and up-regulate biological activities of human regulatory T cells (Treg). PLoS One. 2010; 5: e11469. doi: 10.1371/journal.pone.0011469.

140. Logozzi M, De Milito A, Lugini L, Borghi M, Calabro L, Spada M, Perdicchio M, Marino ML, Federici C, Iessi E, Brambilla D, Venturi G, Lozupone F, et al. High levels of exosomes expressing CD63 and caveolin-1 in plasma of melanoma patients. PLoS One. 2009; 4: e5219. doi: 10.1371/journal.pone.0005219.

141. Rabinowits G, Gercel-Taylor C, Day JM, Taylor DD, Kloecker GH. Exosomal microRNA: a diagnostic marker for lung cancer. Clin Lung Cancer. 2009; 10: 42-6. doi: 10.3816/CLC.2009.n.006.

142. Tanaka Y, Kamohara H, Kinoshita K, Kurashige J, Ishimoto T, Iwatsuki M, Watanabe M, Baba H. Clinical impact of serum exosomal microRNA-21 as a clinical biomarker in human esophageal squamous cell carcinoma. Cancer. 2013; 119: 1159-67. doi: 10.1002/cncr.27895.

143. Ren JG, Man QW, Zhang W, Li C, Xiong XP, Zhu JY, Wang WM, Sun ZJ, Jia J, Zhang WF, Zhao YF, Chen G, Liu B. Elevated Level of Circulating Platelet-derived Microparticles in Oral Cancer. J Dent Res. 2016; 95: 87-93. doi: $10.1177 / 0022034515592593$.

144. Zlotogorski-Hurvitz A, Dayan D, Chaushu G, Salo T, Vered M. Morphological and molecular features of oral fluid-derived exosomes: oral cancer patients versus healthy individuals. J Cancer Res Clin Oncol. 2016; 142: 101-10. doi: 10.1007/s00432-015-2005-3.

145. Aushev VN, Zborovskaya IB, Laktionov KK, Girard N, Cros MP, Herceg Z, Krutovskikh V. Comparisons of microRNA patterns in plasma before and after tumor removal reveal new biomarkers of lung squamous cell carcinoma. PLoS One. 2013; 8: e78649. doi: 10.1371/ journal.pone.0078649.

146. Melo SA, Luecke LB, Kahlert C, Fernandez AF, Gammon ST, Kaye J, LeBleu VS, Mittendorf EA, Weitz J, Rahbari N, Reissfelder C, Pilarsky C, Fraga MF, et al. Glypican-1 identifies cancer exosomes and detects early pancreatic cancer. Nature. 2015. doi: 10.1038/nature14581.

147. Li J, Liu K, Liu Y, Xu Y, Zhang F, Yang H, Liu J, Pan T, Chen J, Wu M, Zhou X, Yuan Z. Exosomes mediate the cell-to-cell transmission of IFN-alpha-induced antiviral activity. Nat Immunol. 2013; 14: 793-803. doi: 10.1038/ ni.2647.
148. Akao Y, Khoo F, Kumazaki M, Shinohara H, Miki K, Yamada N. Extracellular disposal of tumor-suppressor miRs-145 and -34a via microvesicles and 5-FU resistance of human colon cancer cells. Int J Mol Sci. 2014; 15: 1392 401. doi: 10.3390/ijms15011392.

149. Eichelser C, Stuckrath I, Muller V, Milde-Langosch K, Wikman H, Pantel K, Schwarzenbach H. Increased serum levels of circulating exosomal microRNA-373 in receptornegative breast cancer patients. Oncotarget. 2014; 5: 965063. doi: 10.18632/oncotarget.2520.

150. Huang X, Yuan T, Liang M, Du M, Xia S, Dittmar R, Wang D, See W, Costello BA, Quevedo F, Tan W, Nandy D, Bevan GH, et al. Exosomal miR-1290 and miR-375 as prognostic markers in castration-resistant prostate cancer. Eur Urol. 2015; 67: 33-41. doi: 10.1016/j. eururo.2014.07.035.

151. Matsumura T, Sugimachi K, Iinuma H, Takahashi Y, Kurashige J, Sawada G, Ueda M, Uchi R, Ueo H, Takano Y, Shinden Y, Eguchi H, Yamamoto H, et al. Exosomal microRNA in serum is a novel biomarker of recurrence in human colorectal cancer. Br J Cancer. 2015; 113: 275-81. doi: 10.1038/bjc.2015.201.

152. Du M, Liu S, Gu D, Wang Q, Zhu L, Kang M, Shi D, Chu H, Tong N, Chen J, Adams TS, Zhang Z, Wang M. Clinical potential role of circulating microRNAs in early diagnosis of colorectal cancer patients. Carcinogenesis. 2014; 35: 2723-30. doi: 10.1093/carcin/bgu189.

153. Rotelli MT, Di Lena M, Cavallini A, Lippolis C, Bonfrate L, Chetta N, Portincasa P, Altomare DF. Fecal microRNA profile in patients with colorectal carcinoma before and after curative surgery. Int J Colorectal Dis. 2015; 30: 8918. doi: 10.1007/s00384-015-2248-0.

154. An T, Qin S, Xu Y, Tang Y, Huang Y, Situ B, Inal JM, Zheng L. Exosomes serve as tumour markers for personalized diagnostics owing to their important role in cancer metastasis. J Extracell Vesicles. 2015; 4: 27522. doi: 10.3402/jev.v4.27522.

155. Thery C. Cancer: Diagnosis by extracellular vesicles. Nature. 2015; 523: 161-2. doi: 10.1038/nature14626.

156. Lee J, Kohl N, Shanbhang S, Parekkadan B. Scaffoldintegrated microchips for end-to-endin vitrotumor cell attachment and xenograft formation. Technology. 2015: 1-10. doi: 10.1142/s2339547815500065.

157. Cheng G. Circulating miRNAs: roles in cancer diagnosis, prognosis and therapy. Adv Drug Deliv Rev. 2015; 81: 7593. doi: 10.1016/j.addr.2014.09.001.

158. Arroyo JD, Chevillet JR, Kroh EM, Ruf IK, Pritchard CC, Gibson DF, Mitchell PS, Bennett CF, PogosovaAgadjanyan EL, Stirewalt DL, Tait JF, Tewari M. Argonaute2 complexes carry a population of circulating microRNAs independent of vesicles in human plasma. Proc Natl Acad Sci U S A. 2011; 108: 5003-8. doi: 10.1073/ pnas. 1019055108 .

159. Gallo A, Tandon M, Alevizos I, Illei GG. The majority of 
microRNAs detectable in serum and saliva is concentrated in exosomes. PLoS One. 2012; 7: e30679. doi: 10.1371/ journal.pone.0030679.

160. Trajkovic K, Hsu C, Chiantia S, Rajendran L, Wenzel D, Wieland F, Schwille P, Brugger B, Simons M. Ceramide triggers budding of exosome vesicles into multivesicular endosomes. Science. 2008; 319: 1244-7. doi: 10.1126/ science. 1153124.

161. Marsh M, van Meer G. Cell biology. No ESCRTs for exosomes. Science. 2008; 319: 1191-2. doi: 10.1126/ science. 1155750 .

162. Peng Q, Zhang S, Yang Q, Zhang T, Wei XQ, Jiang L, Zhang CL, Chen QM, Zhang ZR, Lin YF. Preformed albumin corona, a protective coating for nanoparticles based drug delivery system. Biomaterials. 2013; 34: 8521-30. doi: 10.1016/j.biomaterials.2013.07.102.

163. Batrakova EV, Kim MS. Using exosomes, naturallyequipped nanocarriers, for drug delivery. J Control Release. 2015. doi: 10.1016/j.jconrel.2015.07.030.
164. Alvarez-Erviti L, Seow Y, Yin H, Betts C, Lakhal S, Wood MJ. Delivery of siRNA to the mouse brain by systemic injection of targeted exosomes. Nat Biotechnol. 2011; 29: 341-5. doi: 10.1038/nbt.1807.

165. Haney MJ, Klyachko NL, Zhao Y, Gupta R, Plotnikova EG, He Z, Patel T, Piroyan A, Sokolsky M, Kabanov AV, Batrakova EV. Exosomes as drug delivery vehicles for Parkinson's disease therapy. J Control Release. 2015; 207: 18-30. doi: 10.1016/j.jconrel.2015.03.033.

166. Kim MS, Haney MJ, Zhao Y, Mahajan V, Deygen I, Klyachko NL, Inskoe E, Piroyan A, Sokolsky M, Okolie O, Hingtgen SD, Kabanov AV, Batrakova EV. Development of exosome-encapsulated paclitaxel to overcome MDR in cancer cells. Nanomedicine. 2015. doi: 10.1016/j. nano.2015.10.012. 